at 
BRARIES ${ }^{z}$ SMITHSONIAN INSTITUTION ${ }^{z}$ NOILNLIISNI NHINOSHLIWS

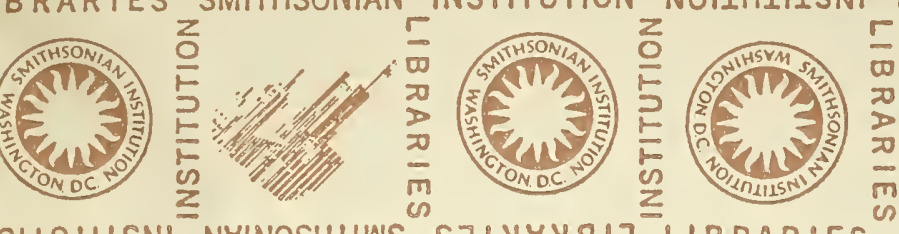

OLIIISNI

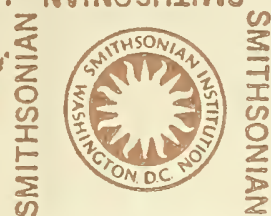

BRARIES SMITHSONIAN

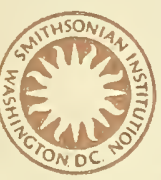

$\frac{\pi}{a}$

I NYINOSHLIWS
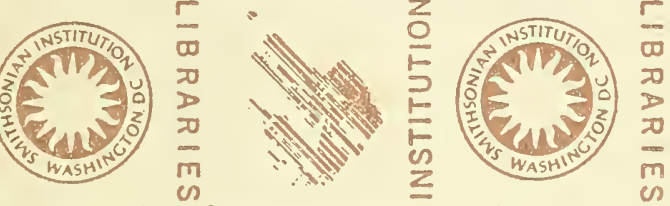

INSTITUTION
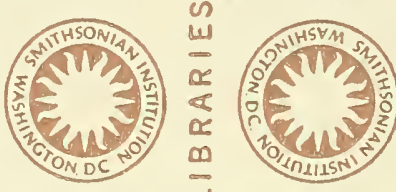

LIBRARIES

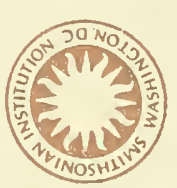

$z$
0
5
5
$E$
$E$

SMITHSONIAN
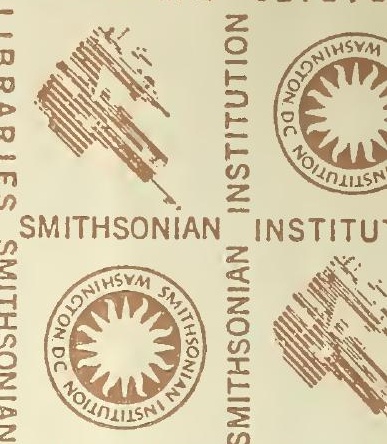

INSTITU

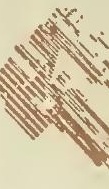

S $\exists I \forall \forall \forall$

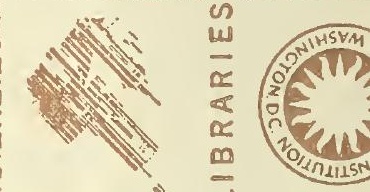
SMITHSONIAN

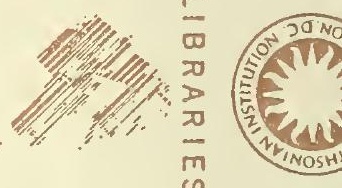

NHINOSHIIWS S
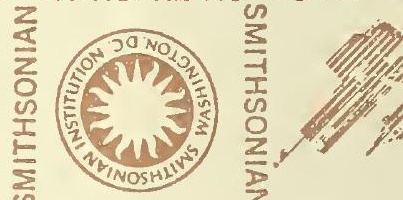

LIBRARIES SMITHSONIAN

INSTITU
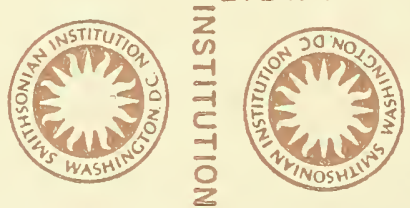

$\omega$
$w$
$\alpha$
$\alpha$
$\infty$

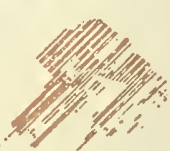

$z$
s
$=1$
$=1$
0

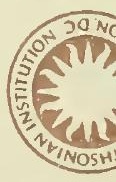

S $318 \forall 8$
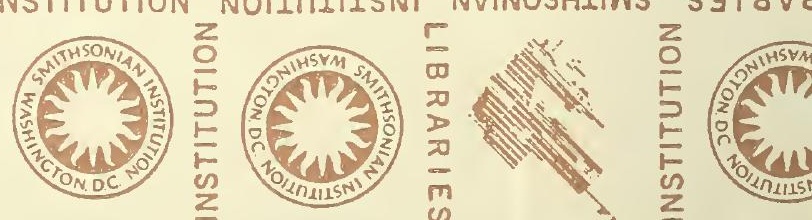

SMITHSONIAN INSTITU
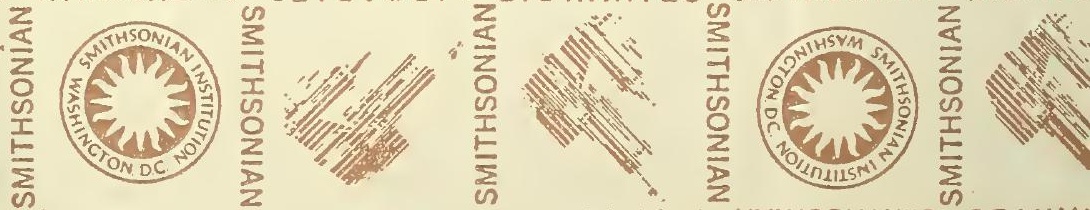

$5 \exists 18 \forall$
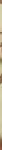
ARIES SMITHSONIAN INSTITUTION NOILNIIISNI NVINOSHLIWS

s
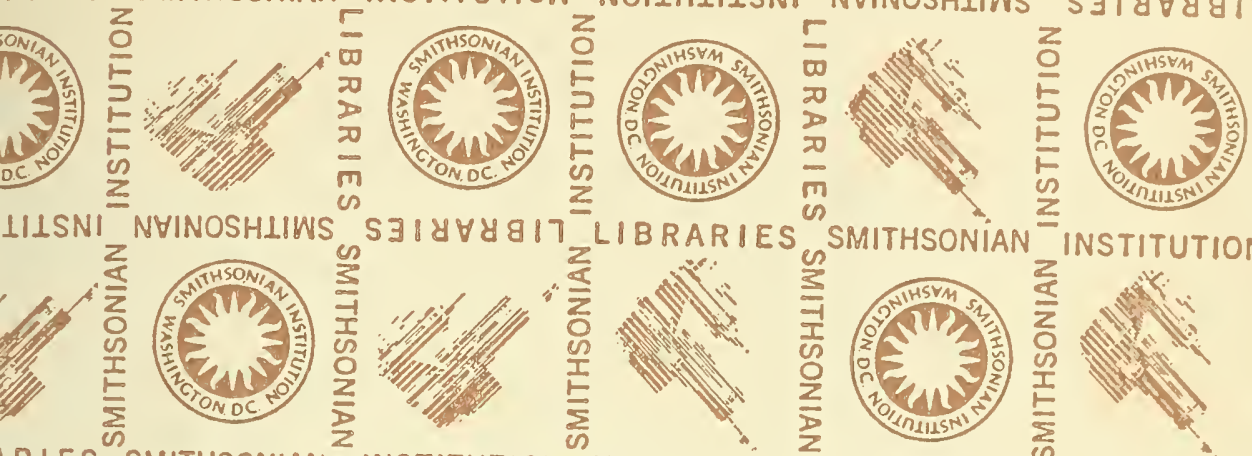

INSTITUTION

IRIES SMITHSONIAN

INSTITUTION NOIINHISNI NHINOSHLIWS

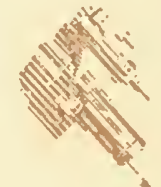

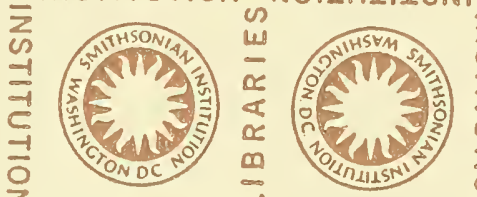

(1)

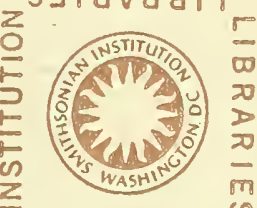

TIBRAR IES

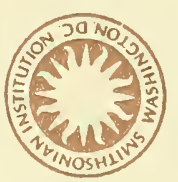

NOILRIIISNI
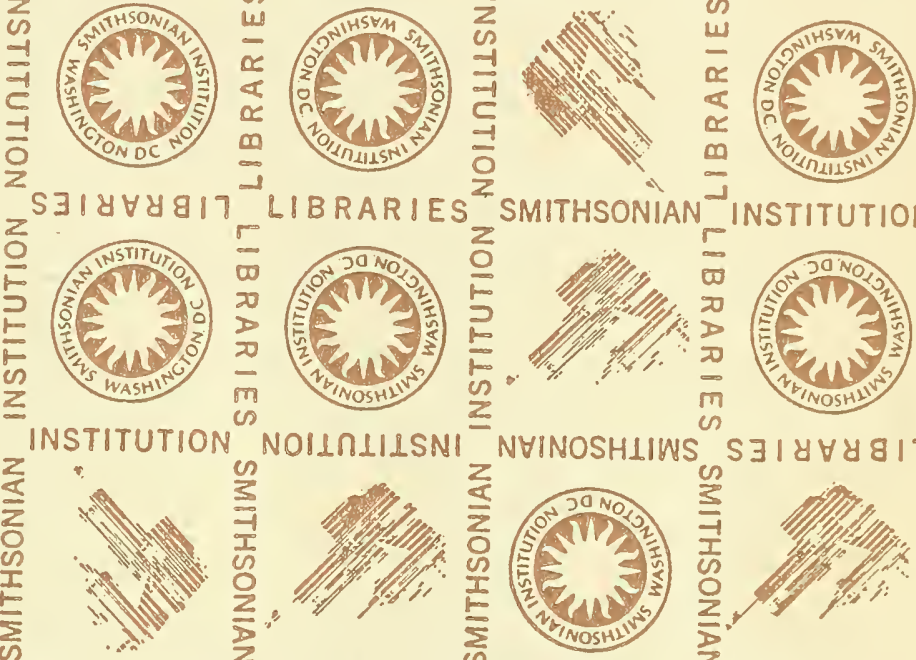

SMITHSONIAN

足
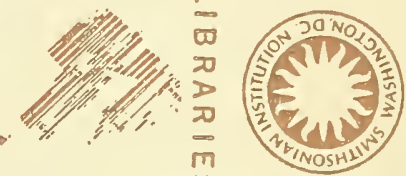

글

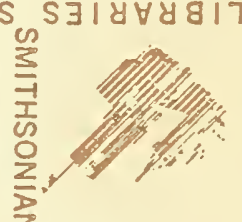

IISNI NHINOSHIIWS SJIYY\&G17 LIBRARIES SMITHSONIAN
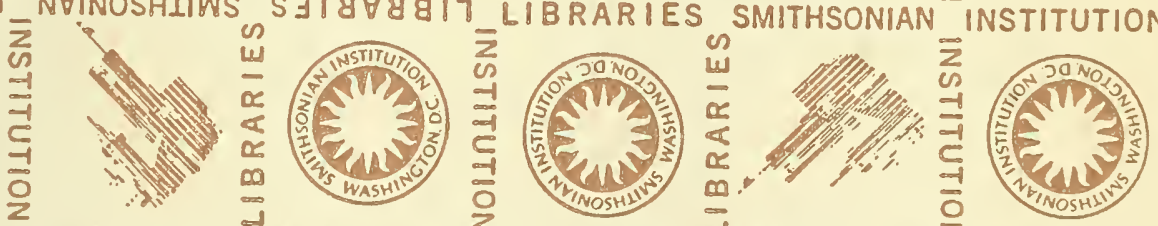

RIES SMITHSONIAN
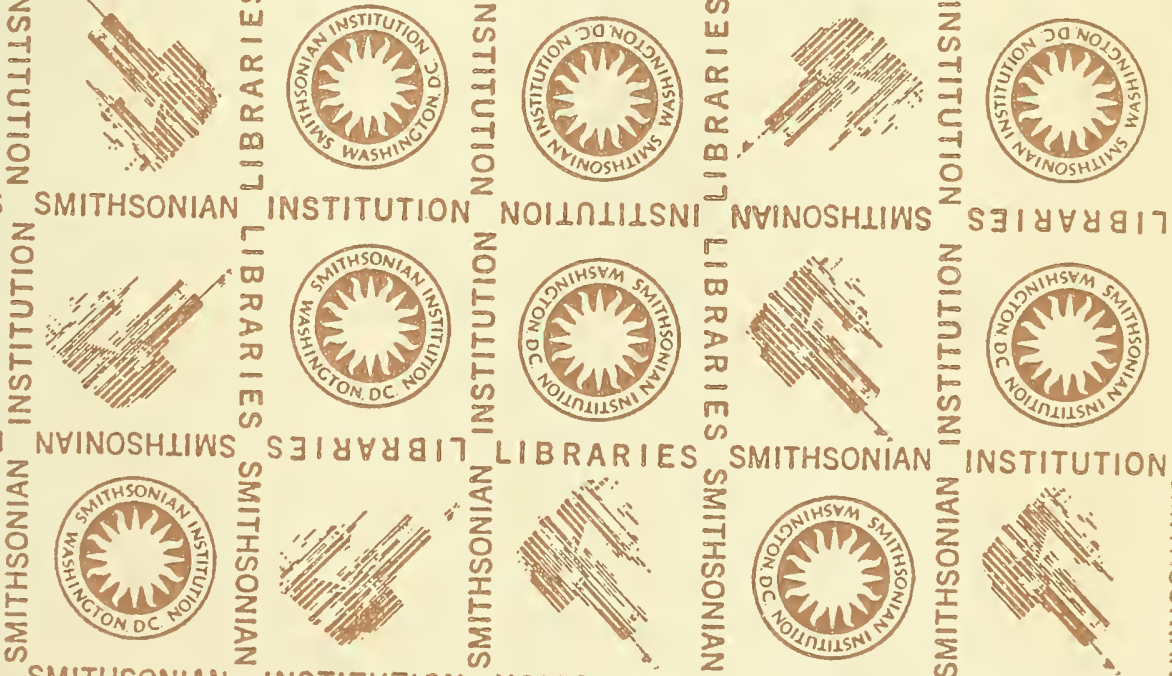

RIES SMITHSONIAN

INSTITUTION NOIIOLIISNI

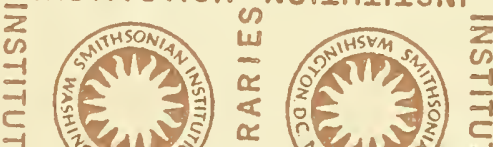
NYINOSHLIWS
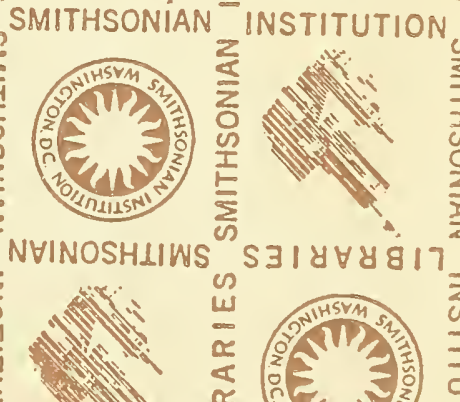

$\bar{z}$ 





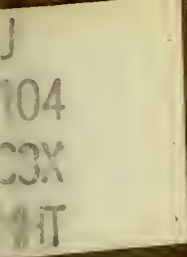

THE ART AND SCIENCE OF WAR Versus

THE ART OF FIGHTING

By

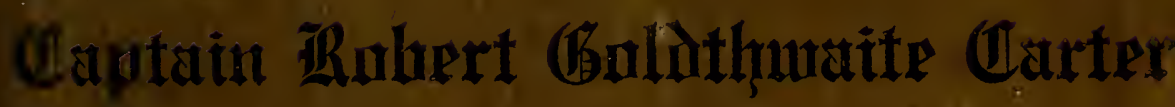

U. S. ARMY 
The cons tents and hest wishes

$Z$ the mantras. Rel eater

THE ART AND SCIENCE OF WAR

Versus

THE ART OF FIGHTING

$B y$

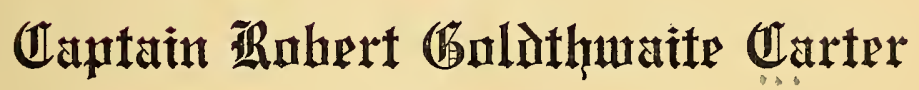

U. S. ARMY

Library Army + Navy Chr washington $\Phi G$

WASHINGTON, D. C.
NATIONAL PUBLISHING CO.. PRINTERS, 1922 


$$
\text { A. }
$$




\section{The Art and Science of War}

\section{Synonymous Terms (?)}

W

HEN the writer entered the army in 1862during our great Civil War-at the age of sixteen, he heard much about the Art and Science of War, and the discussions thereon-pro and con. A brother had just graduated from West Point and had been in command of a company of regular infantry in the first battle of Bull Run and at Gen. George B. McClellan's headquarters-as he was then commanding the Army of the Potomac-and, later, was at Burnside's, Hooker's and Meade's.

The writer was just fresh from school, a raw, untrained volunteer, and had not learned to differentiate those well-worn phrases. To his green, unitiated, and undisciplined mind, at that youthful age, these two phrases -the "Art and Science of War," and the "Art of Fighting"- -seemed to him to be synonymous terms. It was not until he had been through the maelstrom of campaign and battle under such commanding generals as McClellan, Burnside, Hooker and Meade at Antietam, Fredericksburg, Chancellorsville, Gettysburg, etc., and emerging from that experience to enter West Point in 1865, and, soon after, had taken up the study of the Art and Science of War, with all of the principles applying thereto, that he began to go back a little and doubt his first youthful diagnosis, definition or interpretation of this phrase which had been rung with so many varying changes on those campaigns and in those bloody battles which were so potent in checking, in a degree, our ardent and most enthusiastic patriotism, and preconceived ideas of the glory and pleasure of war. Those two terms are not, nor will they ever be, synonymous. 
He turned backward for reflection. There was, perhaps, one incident during his course at the Military Academy which materially helped him to chew this cud.

\section{The Irate and Non-Militant Professor}

One day at recitation he had a subject in "Mahan's Advance Guard and Outposts." The author and professor was present. The writer jotted a few headings on the blackboard, perfectly confident of his subject and getting a maximum mark, as he had had to perform this duty many times in the course of his battle service. He practically ignored the text-which proved to be fatal to his ambition. He had scarcely begun his recitation before the professor-who had graduated at the head of his class at West Point, and second in his class at the Écôle Polytechnique of France (he would have graduated at the head had he not been an American) - but who, as an engineer, had never been in battle or heard a hostile shot, or had even ever seen the principles of advance and rear guard, pickets, outpost and vidette pickets, flanking columns, etc., of his own textbook practically demonstrated in the camps or along the lines of a large fighting army. This professor arose and angrily exclaimed, "No, sir! that is all wrong!" "But, professor, that is just as I have performed that duty practically as a soldier many times during my battle service in the Civil War." Still,angry, the professor shouted, "I don't care what you did or what you saw during the Civil War, you stick to the text!" When I ventured to mildly argue with this irate disciple and exponent of the Art and Science of War, saying that under certain conditions it was found necessary to depart sometimes from the cut and dried formulas and rules of well-known textbooks on the subject, and improvise in a thoroughly practical manner certain changes, he shouted, "I want to hear nothing 
further from you. Sit down, sir!" And I received a mark of 1.5 or 1.7 on a 3.00 recitation. The writer began to open his eyes. The dawn had come. Light began to break in upon his hitherto benighted soul. He had just begun to study the "Art and Science of War." He had before been simply an humble boy volunteer fighter in the old Army of the Potomac. Why should he stand there and argue with the exponent of that art? Visions of his future profession began to loom up, and he quietly chewed the cud and ruminated. He is the same professor who was sent for by the War Department in 1861 to devise a system of defensive fortifications for the Capital, and having suggested and drawn up elaborate plans for a permanent or semi-permanent system of Vauban's line of circumvallation, and being told that what was needed was something that could be of immediate use, as they could not wait four or five years for the masonry, etc., he became incensed, left Washington in high dudgeon and his services were not again called for nor was he heard from again until by sheer ill-luck the writer clashed with him on a subject so dear to his heart-the theoretical safeguarding of a great army in its camps and on an offensive campaign during the stress of a long and bloody war. $\mathrm{He}$ (the professor) was not, nor could he be converted. into a practical fighter.

When the writer was asked, after graduation from West Point, "What did you learn during your studies there of the Art and Science or the Theory of War and the application of its principles-and about real battle conditions as you saw them, or how those principles worked out on the fighting or battleline," he always related the two foregoing incidents and freely confessed that nowhere in any text book on tactics or grand strategy was there any hint, or anything tangible laid down which gave any real, definite information or knowledge respecting the method or "Art of Fighting," 
or sudden, unlooked for conditions arising (and they are likely to change every few minutes) after the plan of battle had, according to the well-known principles governing such a plan, or the tactical formations and maneuvers, been worked out.

\section{No Cut and Dried Plans or Fixed Rules in War}

He found that there was not, because there could not, be any cut and dried plan covering any particular method or art of fighting. It never has been and never can be written in any book, because all battle conditions are never a fixed but always a varying quantity, and consequently the exact science of mathematics, or of constant quantities cannot apply. He found that really his own personal or individual experience in actual battle under competent leaders who had learned the lesson and "played the game" in the same manner as he had-but not out of books-had been his only teacher or guide, and much of the so-called Art and Science of War, under real battle conditions, was and is still the merest "bunte." This does not apply to the marching, feeding, clothing, care, proper training and skillful leadership in the fighting of men-or, as the writer has chosen to call it, the "Art of Fighting."

Many of the men in high commands whom the writer had looked upon as the greatest living examples or exponents of this "Art and Science of War" and whom he had placed upon the loftiest pinnacles of fame, showed the most dense ignorance of the "Art of Fighting." $\mathrm{He}$ learned that after all of this knowledge gained from books, many of them written by men who, like the old professor he has quoted-had never seen a battlefield or had ever been under fire, but who, taking the wellaccepted abstract formulas as their tests, had hatched, incubated, and published these books and demonstrated them to their students, as the only safe maxims and wise 
guides upon which the average soldier could pin his faith when the grim, black vulture of war had descended upon our unmilitary nation. But, after elaborating upon the evolution of tactics, the grand strategy and maneuvers of armies, the logistics, depots of supplies, hospitalization, sanitation, etc., one could find no word about the Art of Fighting an Army, and the writer was free to confess, after passing through the bloody sweat and hell of battle on those sanguinary fields, that he had never learned anything about the real battle fighting from these books, but had been compelled to retrograde or go back, not to the theory of war, but to the Art and Science of fighting.

\section{Art of Fighting a Constant Factor}

The art and science of war then, as studied from books, and the principles governing the same, may or may not be applied in a real wildcat battle, but the art of fighting, while it may or may not be an inherent or cultivated trait, depending, it is believed, upon one's environments, it must always be employed in any and every battle. It is absolutely certain that no amount of military education furnishes such an art. Then the query naturally arises, what does?

It developed during that four long years of Civil War that many of those in high commands, as has already been stated-and who were considered as the most scientific and best-educated soldiers in the United States, well versed in the art and science of war, proved to be the poorest fighters. The one most glaring example of the truth of this assertion can be found in Gen. Henry W. Halleck, who, as a sort of directing commanding general or chief of staff, had tried to direct from Washington, remote from the real fighting zones-the operations of our widely separated armies in the field by the telegraph or long-drawn-out orders. No more dismal failure could 
be cited. No amount of book training or theoretical study of the "Art and Science of War" could ever teach Halleck the "Art of Fighting." He was no fighter except on paper and with his mouth. A "tar bucket night fight," referred to later on, would have given him a stroke of apoplexy. We had a lot of "book-worm" fighters just like him at that period. We have had them since; we have them with us now, and will in the future.

\section{Book-Worm Soldiers vs. "Tar-Bucket" Scrappers and the "Forest City" Manhandlers}

The writer, in his early boyhood, lived in a New England seaport city. Without going into the specific causes for such an apparently unnatural and very strange, almost anomalous condition which existed in this city during the early ' 50 s of the last century, the city was divided into four distinct fighting zones or sectionsthe division not being on or along strictly racial linesor on any other lines that has ever been explained. These sub-divisions or zones were called "Hogtown" (Yankees), "Gorham's Corner" (Irish), "Green Streeters" or "Cōvers," and "Washington Streeters" (negroes and mixed). They comprised all of the boys of a fighting age living in the west, south, north, and east divisions, and along and including certain streets. On many nights in winter these boys would meet on the corners of these streets in their respective neighborhoods, and with little or no provocation start a fight with their fists and sawedoff broomsticks-sometimes with snowballs. But it was reserved for one night in the year, and that the night of February 22, "Washington's Birthday," for the various clans to gather. The "Hogtown" and other clans were generally marshaled or led by the American mates and husky Yankee sailors of ships in the harbor. At that period many square riggers, barques, barquentines, brigs, brigantines, hermaphrodite brigs, coastwise topsail 
schooners, and fishermen were lying in at the docks with idle crews.

For many weeks prior to this date, the wharves and warehouses were scoured for wood (pitch pine), tarred rope, tar, rosin, whale oil, or anything that would make a big blaze and a hot fire. Sugar hogsheads and hardwood barrels were obtained, and these mounted on large, stout sleds, and manned by the boys of those sections, strung out on long ropes, everybody armed with a big camphene or tar torch and a sawed-off broom handle, his pockets bulging with snowballs which had been well soaked and frozen the night before, made up the fighting gangs. This sled-now in full blaze as a challenge-was hauled out by this thoroughly patriotic (?) and zealous band of fighters over the hard, packed snow to do battle for their end of the burg and win a victory or spell defeat. It was a crusade, and every enemy head that showed up anywhere outside of the geographical limits was to be hit, and when a crowd was so far whipped or conquered as to ingloriously flee and abandon their burning "tar bucket," barrel or hogshead, the latter was most unceremoniously caught up and dumped bodily upon the victors' barrel and on went the shouting crowd singing some familiar sailor "Chantey" song-for new fields and barrels to conquer. This was called "Tar-bucket night" and was the regular annual event of each winter season for many years. No such carnival was ever known to exist in any other city in the country. Some years ago some local paper of that city attempted to give the origin of such a celebration on that particular night. The writer does not now recall the reason then given-but it probably had its inception among the sailors of that period. Neither the Mayor nor Police Department of the city ever interfered in any way with the rights and guaranteed liberties and "pursuit of happiness" of these bands of fighters. It was their night. Now the risk is so great of fire that a few years ago this old-time custom had de- 
generated into a small bonfire being permitted in one of the public squares-but with no fighting. The "Art of Fighting" has waned and died out there as a "pussyfooted pacifism" has crept in and increased.

A similar custom existed in Boston about this same period-numerous encounters taking place across old Craigie's Bridge, connecting Boston and Charlestown, between the Irish of the "North End," "Copp's Hill" and about "Dock Square" and the boys of "Bunker Hill" and "Sullivan Square" and "Navy Yard." Rocks and clubs were freely used, but no such event as "Tar Bucket Night" ever took place in these two historic towns. It remained as previously stated, for the Forest City of the "Dirigo" ("I Lead") State to initiate and maintain the curious custom here given which was to train so many American fighters for the Civil War period.

There were some broken or sore heads, many black eyes and swollen noses. Little or no strategy and no tactics were employed. It was simply a rough neck fight, every mother's son doing his level best-and a fight to the finish. It was what the writer chooses to term "The Art of Fighting," with no study of any books bearing upon the Art and Science of War or anything else. There was little or no tactical formation as is known today in the study of military science, regarded so necessary by some in maneuvers on a battlefield. The larger boysranging from 17 to about 10 (boys large enough to carry a torch and handle a sawed-off broomstick), led by the 18 to 21 year old magnificent American mates-"manhandlers" who had had the sea training and discipline aboard great square-rigged clipper ships and had made their two or three year cruises to Japan, China, India and the Philippines, or "Around the Horn," who were fighting for the honor and reputation of the sections in which they had been born and reared. In other words, what the boys of that period most needed was the fighting spirit and "guts," and true, tried leaders, and no theo- 
retical book bunk. Such a fighting spirit and morale cannot be gleaned from books of tactics or grand strategy.

There were certain whistle or halloo signals, made by the mates or boatswains-calls for identification of the local fighters, and used for concentration or dispersion, and for the small boy reserves-who were not allowed in the front rank formations - to bring up extra ammunition in the shape of frozen snowballs. On one occasion the best leader we had-a young Yankee mate ("Dave" Keazer), just in from a long cruise to China, was struck in the back of the head by a large iron bolt thrown by the "Green Street" enemy, who had sneaked around the corner, coming up in the rear, just as our "Hogtown" boys were hauling off a particularly fine, new blazing "tarbucket" which had been captured after a most desperate fight. With a sled as an ambulance our hero was hauled home for repairs. He was out in a few days, none the worse for his injury. The most sanguinary engagements were generally in the "Gorham's Corner," or Irish zone, for here, in addition to the young Irish sailors of that section, sometimes pretty well "lit up" with "booze"-for that was the rum section of the city-they were generally helped out by the mothers, wives, and sweethearts of these fighting sons of Erin, and they fought with the zeal and fury of wildcats, their ammunition consisting of frozen snowballs, horseshoes and chamber missiles thrown from the windows upon our unprotected heads. Helmets had not then been thought of.

The balance of the winter, when not skating and coasting on Saturday afternoons or when not attending school, each section of the city was still further subdivided-generally according to localities or streets-into war-like bands, which, building snow forts in vacant lots at or near the corners of wide streets, and choosing leaders, endeavored to capture by every artifice and stratagem, and frontal and rear or flank attacks or storming columns these miniature works. These fights were snow battles 
only and lacked the sawed-off broomsticks and sailor leadership, and consequently not any danger of serious injury, although hundreds of boys were engaged in these strictly daylight actions and close hand-to-hand combats. We were, although unconsciously, learning the "Art of Fighting" then, all of which was fitting us for what was to come less than five years later on the bloody battlefields of the Civil War, for probably seventy-five per cent of those boys who had engaged in those "Tar Bucket Night" and snowball battles through the streets of that dear old city went in the Maine regiments (mostly in the Seventeenth Maine) which made up our fighting volunteer armies in the field. They made the finest soldiers of Hooker's and Kearney's divisions or that the world has ever seen-which was demonstrated after being tried out for four long years in the crucible of one of the greatest and most sanguinary struggles ever recorded on the pages of the history of the world.

Among these gallant souls were four sons of William Pitt Fessenden, for many years, and when he died, a senator from Maine, and Secretary of the Treasury in the cabinet of Abraham Lincoln. One of these sons was killed at the battle of Second Bull Run while serving on the staff of Gen. Tower. Another lost his leg at the battle of Shiloh and died a brigadier-general on the retired list of the United States Army. While the other two rendered most brilliant and distinguished service. None were graduates of West Point. Many of these boys never came back; some are buried in nameless graves. Who can gainsay the fact, however, that those battles in the streets of that quiet seaport city-the city of Longfellow on Casco Bay-not only inculcated the true soldierly spirit - the fighting spirit-and fully impressed upon each and all the true "Art of Fighting," lacking only the necessary instruction after reaching the field, and the experience of the camp, the march, the picket outpost, and direct contact with a real armed enemy, but actually made the 
superb, self-reliant soldiers which they later became. The Maine lumbermen-all perfectly skilled axemen-could put themselves under cover on the outpost or in camp quicker than any men the writer ever saw in the Armyand the President (Abraham Lincoln) was heard to say when riding through our cantonments or winter camps in April, 1863-and passing by the log huts of the Second Maine-uniformly built with streets the same widthcracker box doors and leather hinges, pork barrel chimneys; and all mathematically laid out with almost an engineer's skill-with the Company letters worked out in evergreens in arches over those streets, "That is the finest camp I have ever seen in the Army of the Potomac; they must be loggers!" They were, having come from the Penobscot River region of Maine. They also knew the use of the rifle. None of this was learned from books.

\section{The Non-Scrapping Generals and Military Failures}

McClellan was a thoroughly book-trained soldier, graduating at the head of his class at West Point-in the Engineer Corps. He had learned the "Art and Science of War" more perfectly, perhaps, than any other graduate of his time, and could give those whom the writer has attempted to describe in their snow, ice, and "tar-bucket" battles, "cards and spades" pertaining to all of the formulas for the perfect organization, intensive drill, discipline and esprit de corps of a well-trained army, but he knew little or nothing of the Art of Fighting that army, and it made but little difference whether he had 50,000 or 100,000 men, or whether he outnumbered his enemy two to one, he was always training and preparing and never ready for battle, always exaggerating his enemy into an overwhelming force, a veritable bête noir; always slow, halting, hesitating to begin the real fight-the contest that, sooner or later, must decide the issue-and then at the crucial moment when his very best reserves, which 
he had been holding for a coup de grâce and should have been hurled in to decide the battle then and there, and give the enemy a "knockout" finishing blow, he still held it in leash-idle, expectant, but their fighting power inert and rendered for that battle null and void; all through McClellan's lack of knowledge of the true "Art of Fighting." He got hung up astride the Chickahominy river on the peninsula and fought a portion of his army while the balance remained inactive, permitting the enemy to mass on his right flank - this at a time when, by fighting his magnificently trained and supplied army as a unit and when the spires of Richmond were in full view, he could have captured that city with ease, as is now so well known.

Without a proper personal reconnaissance of the Confederate right flank at Antietam, which, it was known later had been stripped almost to the last man to reinforce the Confederate left, he delayed leaving his headquarters at the Pry House until nearly $1 \mathrm{p}$. m., instead of going to Burnside, staying with him and seeing that his (McClellan's) orders were carried out for an attack at 8 a. m., and by crossing at a shallow ford (Swavely's) about oneeighth of a mile below the bridge ("Burnside's), he could have got on Lee's right flank and swept down his line instead of frittering away his time until noon, and then making a frightfully costly assault in column-a frontal attack across a narrow bridge-almost a causewayagainst an entrenched line on a steep hillside. The Confederate army should have been decisively defeated at Antietam, and Lee either captured or his army destroyed. It is now known that it was what Lee feared and expected.

Burnside was another example of a man who, while he may have known the Art and Science and theory of war - and was a noble example of unselfish patriotism, and devoted to his country and the Union cause-knew nothing of the "Art of Fighting" an army. To cite the battle of Fredericksburg, with its bloody slaughter, useless sacrifice and inglorious withdrawal on that gloomy and bitter 
December night, or to attempt an analysis of all the unnecessary blunders and stupid orders which were notoriously and conspicuously the cause of the defeat of the Union army, would alone almost fill a volume, and in the end prove a useless waste of time. Suffice it that neither at that nor in any other battle in which he participated did he show that he ever knew or had learned the true "Art of Fighting."

Hooker possessed that art to a most eminent degree. Without knowing much about the Art and Science of War, he called himself and was called by his friends "Fighting Joe." That unique recommendation to Abraham Lincoln after his experience with McClellan, Pope and Burnside, made such an impression on him that it secured for Hooker his elevation to the command of an army, which, while it had met with some most disheartening reverses, was still the magnificent Army of the Potomac waiting for somebody who would know how to fight it. Unfortunately for Hooker, however, and for his loyal friends, although he had promised Mr. Lincoln and those friends that he would control it, he had the most unfortunate and almost fatal habit of getting drunk at the wrong time and in the wrong place, and it proved so destructive to his activities that his Art of Fighting became a misplaced talent and, as at Chancellorsville, he came to grief while in an inert and maudlin state-so afterwards through that habit and an inclination to arrogance and insubordination when serving under a commanding general like Grant, his fighting efforts, with but few exceptions, were most unfortunate failures and disasters. It may not be well known, but that plan of the campaign of Chancellorsville, his almost marvelous march of concentration to the field and the details of battle were never incubated in the brain of Hooker, but were worked out through a conference between Generals G. K. Warren and Henry J. Hunt-which was submitted to Hooker and accepted. 


\section{Meade's Lost Opportunity}

Meade was, during most of the period of that war, a sick man and really unable to stand the hardships incident thereto-all of which accounts for much of the irritability, irascibility and bad temper which he was apt to show, and which at times reduced him almost to a nervous wreck. His extreme caution at the battle of Gettysburg lost the Union army the opportunity of making Lee's defeat a most crushing one, if, perchance, it had not succeeded in preventing his recrossing the Potomac and the possibility of the capture of his entire army when he (Lee) found that his pontoon train had been captured and he was compelled to improvise a makeshift bridge to cross that river. A bold dash-a master stroke -a general advance upon Lee's exhausted, dispirited men that night would have proved an almost certain success.

The writer was there-being on picket that night during Lee's crossing-and had an intimate knowledge of Lee's perilous position through deserters from the Confederate lines who, coming in on our front, were sent into headquarters with this most valuable information, which should have led to an immediate advance to the river where the enemy-according to their statementswas huddled in a more or less disorganized and demoralized condition.* The slight breastworks we went over the next day were low and hastily thrown up and could hardly be called a "strong, defensive line," as has so often been declared by the historical falsifiers of that period who wrote up the campaign, but who, like "our artists on the spot," were not there. The fighters along the line and the alert pickets on the outposts often knew more about the situations on the front than either the

*Note-For a confirmation of these broad statements see "Military Memoirs of a Confederate," by General E. P. Alexander. Pages 432, 439 and 441 . 
commanding general or the corps, division and brigade commanders. Meade lost a very great opportunity. It was not timidity that led him to permit Lee to move his army back into Virginia, because that would be charging him with cowardice, and Meade was no coward. This was shown by the ability and boldness with which he had handled his army on the field. But he was overcautious to the extreme and would risk nothing when he had nothing to lose but everything to gain; all this at a critical moment. Having defeated Lee upon Pennsylvania soil he was more than willing to let Lee's beaten army get safely away without further chances.

He listened to a council of war, and while his bravery and skill in conducting the operations against Lee's army, after being placed in command of the Army of the Potomac but for such a very short period, cannot be questioned - he finally lacked the audacity, boldness and necessary quick judgment or Art of Fighting his army that depressing, rainy period to a knockout-a solar plexus-blow and securing a decisive victory and perhaps terminating the war right then and there. But, "Quien Sabe!" We have some optimistic individuals today of the "Pussy Foot Pacifist" type who are always ready to declare-as some did then, that a "Good and wise Providence" was not quite ready for the war to close just then, and Meade got the full benefit of such a chunk of wisdom. Even Lincoln overlooked such extreme caution, for Meade, feeling that there was an implied censure in Lincoln's message to him after the battle, tendered his resignation-which Lincoln, out of regard for the sensibilities of such a brave man, refused to accept.

\section{Grant's Qualities as a Real Fighter and Military Leader}

Grant had never made a study of the "Art and Science of War." He did not need to, for he possessed the other quality_ "The Art of Fighting"- - to such an eminent de- 
gree that it was unequaled except, perhaps, by two other men in our entire army. A writer has recently said of him:

(William L. McPherson in the New York Tribune of April 24, 1922.) "There was something puzzling and enigmatic about Grant's military career. He was a graduate of West Point, a trained officer, not a self-educated one. He belonged to our military hierarchy. Yet no one could have had less of the temperament and esprit of the soldier than he had. He was hardly a soldier in the sense in which Sherman, McPherson and Reynolds, on the Union side, or Lee, Jackson, and Joseph E. Johnston on the Confederate, were soldiers. He had a profound distaste for the profession of arms. *** He was indifferent to military glory. He took no interest in the science of war (if you admit that there is such a thing, and Foch certainly questions it). He never read works on strategy and knew little of tactics beyond what he learned at West Point. *** He once said, when asked the question, that he had never paid any attention to such a celebrated military authority as Jomimi. *** When it was undertaken by some citizens of Boston after the Civil war to give Grant a library, it was discovered that he had no military books whatever. Imagine a French or German army commander who had never studied the military classics. *** Grant had a quality, however, which carried him to the front $* * *$ and kept him there. It was a moral quality. Charles A. Dana said that "he had a temper that nothing could disturb, and a judgment that was judicial in its comprehensiveness and wisdom' * * * he never experienced trepidation upon confronting an enemy. Sherman said: 'When I go into battle I am always worrying what the enemy is going to do-Grant never gives a d-n.' Grant never hesitated about fighting."

He knew the Civil War could only be won by fighting *** and was satisfied that the North would win 
because of superiority of numbers and resources. Lincoln instinctively appraised that virtue, and said: "Here is a general who fights!" There is nothing to show that Grant ever studied war in the way in which war colleges study it. $* * *$ He once admitted, in reply to a question, applying Hardee's Tactics without having read or studied it through, it having been adopted after he left West Point. *** He cared nothing for the refinements of theory. "I never maneuver!" he once said to Meadeand yet his Vicksburg and Chattanooga campaigns stand out as a finished and masterly demonstration of the Art of War. How did this man, who was without "Military Culture," in Foch's sense, rise to such heights of military competency?" Lincoln answered this question when he declared: "Here is a general who fights"-and the writer adds, he understood not really the Art and Science of War as the ordinary, educated, professional soldier understands it because he did not nor would not study it. It might be that he had almost an intuitive sense of that art -but his true "Art of Fighting" was seldom if ever equalled. While he loathed war, he fought only on the theory that there was no other way out, and fighting, fighting, and still more fighting meant ultimate success. In his Wilderness, Spottsylvania Court House campaign he was called a "butcher," but he kept on fighting because he knew that game and not the kid-glove, swivel-chair art of a Halleck trying to fight battles hundreds of miles away, with only dire results.

Besides all of this well-deserved praise he probably had another most valuable asset and to a much higher degree than those other two men, and that was his serene calmness and the absolute imperturbability of temper referred to by Charles A. Dana. He had that poise and equable balance which, in those days of bloody sweat and daily trial, was liable to upset the men of true, fighting temper and excitable natures. Coupled with all of these qualities, 
together with his persistence and indomitable will, was his rare common sense which took the place of a wagonload of books he might have taken along in the field to teach him to dispose of his enemy scientifically, tactically, and strategically. A given, fixed purpose was always his, mixed with his rare knowledge of the "Art of Fighting." No such word as "can't" was in his vocabulary. The word "failure" never seemed to loom upon the battle horizon, as a remote possibility. An inflexible determination was always his guide. Grant never stopped to consider whether the enemy outnumbered him. He knew what he had come out to do with his army, which he regarded as a fighting machine, a well-trained body of fighting men placed at his disposal for a specific purpose, and he used it for that purpose, to fight an offensive battle if possible, or a defensive battle should it become necessary-but, at all events, to fight it and not permit it to remain in camp, inert and inactive in the face of an enemy, having the life drilled, trained and disciplined out of it; to become restless, and in time stale and useless through dry rot, depletion by desertion, sickness and death. So he went to it and bucked and fought-all of which fulfills the conditions set forth in this paper and to demonstrate the fact that what we will always need in our army are fighting leaders-fighting generals if possible. The latter term is all right, but they must be real fighters as well as real leaders. Grant filled that bill. It was his dogged persistence in fighting to a finish-the real, true fighting spirit that always won out. He was Meade's balance wheel; his conferences with Sherman were timely, friendly and always important and decisive; he acted always as a check to Sheridan's fiery impulses. His methods of attack, while they might not have been strictly in accordance with the book, were a revelation to the enemy. Some of the present generation of soldiers have been fed up with the idea that he was defeated when 
he crossed the Rapidan and made his advance in the Wilderness in an effort to force Lee's left flank, and by turning it take that road towards Richmond or decisively defeat the Confederate army-for that was always Grant's objective-but this was far from being the fact; he merely met with a check, and not succeeding in his first object-on account of the difficulty of deployment and pushing through such a mass of tangled underbrush and chaparral, inability to use his artillery, etc.-he quickly swung to his left and began a pushing, active offensive against Lee's right, which so pleased the roughneck fighters and "tar bucket" scrappers of his army, who were quick to study up his war game and whatever science went with it, that they broke out into cheers that bright May morning, recognizing that at last they were not going to retrograde, turn backward, or recross those hateful rivers-the Rappahannock and the Rapidan. His bulldog tenacity in his "Art of Fighting" was a new and almost astounding feature in the old Army of the Potomac after its long and most discouraging period of dallying with McClellan, Burnside, and Hooker. At last it had found a fighter who knew how to fight it. He had no thought of letting go or of recrossing the Rapidan and had considered no plan by which he could do so. The people, through Congress, were willing to provide the education of these officers in the Art and Science of War, but Congress could not provide fighting generals or that they should learn the Art of Fighting at such a fearful cost. Congress was willing to provide, organize and train as fine an army of volunteers for fighting as the world ever saw. Abraham Lincoln was more than willing to appoint a general to command this trained army of fighters, but what he could not do-and never quite succeeded in doing until Grant was placed in supreme command of all the armies in the field-and insisted upon getting away from the political dry-rot and buncombe 
of Washington and staying with that army of fighters, the Army of the Potomac, and directing all the other armies of fighters-was to find a real, genuine fighter to command these fighting boys, who had never been properly led in battle, so that the war might be quickly finished up. Every one of those trained soldiers soon recognized the rare wisdom of such a far-seeing President when he made that wise selection of the silent Grant, who did not fight with his mouth, and then, before the battle had gone to a finish, recross the rivers we hated so much, but clung with a bulldog tenacity to the end and used the fighting material which had been moulded and placed in his hands for the purpose intended-the speedy suppression of that rebellion.

\section{Sherman-a Striking Example of Strategist, Tactician and All-around Fighter}

Sherman understood the Art and Science of War as well as the Art of Fighting an army, in the judgment of the writer, better than any other officer of all our armies. He was a most versatile and brilliant strategist; a successful tactician, a master of logistics and, as an army commander in the field, moving with the enemy's army always as his objective-always an offensive fighter-he was unsurpassed, and one has only to read of his advance to Atlanta and from Atlanta to Savannah, and his most wonderful campaign from Savannah north to Bentonville, N. C., as his last culminating battle, to place him in the front rank in history as one of the world's greatest commanders. The military student may read for many years to come that great stride of his across rivers, creeks, sloughs, bayous, morasses, and almost impassable swamps-corduroying nearly every mile of the way, living off the country-as every wise commander should always do in great emergencies-always keeping all of 
his animals and transportation in serviceable condition -up to the mark; brushing all enemy opposition from his front, and bringing that magnificent veteran army up on the battle line at Bentonville, N. C., in the finest condition for the last final struggle at the right time, in the right place, and in the right way - every man and animal fit and in fighting condition. There is nothing like it in the history of that great war.

\section{Sheridan-a Real Game Cock Fighter with no "Bunk," "Frills" or "Furbelows"}

Sheridan, more than any other commander in the field, during that great struggle, typified-and in the highest degree-what the writer chooses to term the "Art of Fighting" as distinguished from the "Art and Science of War." He was the incarnation of brute force and the true spirit of battle; a perfect dynamo. With rare good sense, he combined with it a quick and most unerring judgment, without which the ever-changing conditions in battle are apt to go awry and leave a slow, plodding Halleck, the halting, hesitating McClellan with map in hand and a cut and dried plan in his pocket, hung on the fence, or a wind-jamming Hooker-lying absolutely out of the fight for nearly three days in a state of drunken, maudlin paralysis at the "White House" (Bullocks) on the Ely's Ford Road to Chancellorsville-as seen by the writer repeatedly from Sunday noon, May 3, until Tuesday night, May 5 . If exact justice had been done the men who had to endure the suffering inflicted through Hooker's conduct he should have been tried and dismissed, cashiered or shot. In any other country, and at any other period than that of civil war, and when the destiny of this Country or the result of that war were hanging in the balance, that might have been his fate. It was an inexcusable and intolerant act; one that merited swift 
condemnation and the severest punishment.* Sheridan had the keen coup d'oeil and rapid fire action which, to insure success, should go with the hard, sledge hammer "Art of Fighting;" he could hardly be called a strategist or tactician, yet his disposition of his forces, both infantry and cavalry, and his method of posting and fighting his battle units were always productive of the best results. It may not be well known, but to him more than to any other general do we owe the victory of the great and decisive battle of Five Forks which resulted in blocking Lee's escape into the mountains near Lynchburg, Va., and the possible prolongation of the Civil War for at least another year.

As related to the writer by one of his friends, long since dead, and also a dear friend of the late muchlamented General Horace Porter, who was, during the last year of the war the confidential aide and military secretary of General Grant-to whom he (Porter) told of Sheridan's visit to Grant's camp near Farmville while a most desperate effort was being made to head off Lee's infantry columns-and never published in this form, it is now given as a most valuable addition to the history of that war. Grant was camped in the mud. It had rained incessantly for several days; the roads were almost bottomless, practically impassable. Sheridan was across the road near Five Forks vainly endeavoring to stem the force and continued pressing of the Confederate columns under Gen. John B. Gordon,-one of their best officers-

*For full corroboration of this broad statement the reader is referred to the History of the 118th Pa. Vol. Inf. ("Corn Exchange"), page 188. The regiment was in the same brigade as the writer (First Brig., First Div., Fifth Corps) and was on the battle line at this point. We all had to pass the front of Hooker's headquarter tent to obtain water for cooking. This historian states what he saw-and he tells the truth-and this truth could have been established had we been ordered before the Commission on the Conduct of the War when Hooker's conduct was before it. 
who thoroughly understood the "Art of Fighting." $\mathrm{He}$ soon saw that the Confederates were going to push his small brigades of cavalry off the roads and get by unless quick action was taken. Taking a single orderly and on a small single-foot horse he started across the rain-soaked, sodden fields-for there were few or no cross roads in those days-to find Grant, who was about eighteen or twenty miles away. Porter and the staff were sitting around a big log fire in the cold, raw mist and drizzle, and with a sea of mud all about-every man with a serious, discomfited, almost depressed look on his face. Sheridan rode up bespattered with mud from head to foot and soaked to the skin, but with a grim, almost savage look of determination on his face-stern and fixed in its intensity. "Where is the 'Old Man?' was his first and only salutation. "He is there in his tent," was Porter's response. "Will he see me?" "Certainly!" was the reply. A light tap and Sheridan stalked into the cheerless, wet tent. He lost no time in describing the situation. "They are moving forward on your front, you say?" interrogated Grant. "Yes," was the reply. "How can they move in this mud?" "Well, I know that they are, and will soon run over me in spite of all I can do unless I am reinforced," said Sheridan. Not a wheel had turned for more than thirty-six hours and it seemed almost hopeless for men to attempt to move from their bivouacs. It was almost like the famous "Burnside Mud March" of January, 1863-two years before. "How do you know that they are moving?" was Grant's final question. "My best scouts, who are in constant touch with them, come in and tell me so," Sheridan said. "What do you want?" "I want an infantry corps, and no wheel transportation, simply a few pack mules, and three days' rations, to go light, and as quickly as possible. I took great risks in leaving my command this long." Grant, still rather inclined to be incredulous said, "What corps do you want?" "The Sixth, the same corps I had in the valley." "I can't 
give you the Sixth, but you may have the Fifth." "All right!" replied Sheridan, and after a brief nod and goodbye to the staff still hunched up in the rain about the low log fire, and followed by his faithful orderly he was single footing across the wretched, muddy fields back to his cavalry corps, followed in a brief hour or so by the Fifth Corps as a light column with plenty of ammunition, but no collapsible bath tubs or any other unnecessary impedimenta of the World War, and the battle of Five Forks was fought for the possession of the only roads leading south to the vicinity of Lynchburg and the near mountains. The war was won. Thus did Sheridan show the true "Art of Fighting," and thus did this little cavalry gamecock display those same qualities of generalship which resulted in the termination of that war and the surrender at Appomattox-as had been done, only on a smaller scale and with less decisive results-by those boys when on "Tar Bucket" night they had routed the enemy in wellfought battles during those bitter winter nights in that far-off, quiet seaport city by Casco's blue bay-the city of our grey poet's (Longfellow's) boyhood days.

\section{"An Army Fights on Its Stomach"}

After maneuvering their armies for days, and moving hither and yon over areas that were hilly and cut up into numerous ravines tedious for men to march over, and after passing nights without sufficient sleep, the men worn out to the point of weariness, almost exhaustion, it was difficult to get these bookworm generals to fightwhen really that was the real issue-and without which nothing could be settled. Another thing that these nonfighters could never seem to realize, in their study of the Art and Science of War, because it is not mentioned in any book the writer ever saw or read on the subjectand that is where, without ever having served in the ranks, the average man, commanding troops in battle, 
could never fully understand the intelligent needs of the soldier-it was putting men into battle on an empty stomach. A man will not fight on an empty stomach and any general who, upon approaching a battle line, if he has any opportunity afforded him of giving his men a chance to make a cup of coffee and reinforce his stomach with a little food, especially after marching him up hill and down in a series of fool maneuvers, and does not do it, stands a very fair chance of being defeated, or at least of having his name spelled " $M u d$ " for the balance of his life. Here comes in the element of more common sense and less book knowledge. Many a general has met his Waterloo because he thoughtlessly, or from lack of understanding his men, believed he could put them into battle, after a long, exhausting march, and fight them on an empty stomach. This is learned only from one's own experience, and the same common sense that was exhibited by a Grant, Sherman, Sheridan, Thomas, and by a Lee, Longstreet, Jackson and Johnston.

If there was ever committed a more fatal blunder by any man who had profoundly studied the Art and Science of War, than rushing men into battle tired out, perhaps exhausted by a hot, grueling march, on empty stomachs, the writer, having been through that distressing and depressing experience, does not know of it. That is one of the many controlling factors governing the true Art of Fighting. On the last day and night march of nearly thirty-five miles to the near vicinity of Gettysburg, General Geo. Sykes, commanding the Fifth Corps-that true exponent of the Art of Fighting-halted the corps and bivouacked near Boneauville, on the Hanover road at 1 a. m., in the fields, and when we expected to go into battle at daylight, and ordered the men to make coffee and prepare their stomachs for the fight. This was the wise provision of a great soldier, endowed with common sense which cannot be studied from any book ever written on the Art and Science of War. There were some of 
our bookworm non-fighters who had forgotten the very first essential necessary for a good fighter-and that is that "an army fights on its stomach." Many a battle was lost during that Civil War due to the forgetfulness or stupidity of those kinds of fighters who rely more upon tactics and grand strategy than they did upon any common sense they may have possessed in feeding their men -filling their stomachs and getting results thereby. A thoroughly hungry man, especially after he has become practically exhausted after a hard day's march, and has lost faith in the man at the head of the column as a leader and fighter, will not fight a fly; not even a worm.

The Twentieth Maine Volunteer Infantry was in the same division in which the writer served during the Civil War, the First, or Red Maltese Cross Division of the Fifth Army Corps. That regiment was enlisted from all over the State, and was composed of men from at least ten counties-from forest, mountain, and seashore -Penobscot and Androscoggin lumberjacks, salt water sailors, farmer boys-all used to an open-air, out-of-door life-besides many "tar bucket" fighters from the "Forest City." Its first colonel was a young graduate of West Point. He began to lick them into shape by rule of thumb, to discipline and teach them the Art and Science of War so rapidly that it almost took the breath out of the line officers and rank and file. There was no insubordination nor anything approaching a revolt or mutiny, but a universal feeling that he did not understand them nor appeal to their intelligent and zealous efforts to become good officers, and while they had a full realization of the fact that they were raw and green and required a reasonable instruction in their official duties, they did not consider that it added much to their cultivated sense of the "Art of Fighting" and they resisted any effort to impose the martinet methods upon their true American patriotic spirit. This resulted in many of the captains and junior officers being placed in arrest and threat- 
ened with all sorts of punishments, dismissals, dire consequences, etc. This-after the Colonel had been given some advice-had the desired effect and after mutual understanding, good feeling and personal respect had been re-established, it proved to be one of the best fighting regiments to understand the true "Art of Fighting" in the army of the Potomac.

\section{The Supreme Effort of a Fighting Regiment-with Fighting Leaders}

Its supreme effort was made at Gettysburg where it held the extreme left flank of the Union line and where it had to extend its skirmishers in a thin line around the southwest base of Big Round Top. It was in the Third Brigade, commanded by Gen. Strong Vincent, who was killed, and under the soldier Governor of Maine, later president of Bowdoin College, it was engaged late in the afternoon of July 2, 1863, in a rough and tumble mix-up and hand to hand combat in the gorge between the two Round Tops, for their possession, with the Alabama and Texas brigades of Hood's division, Longstreet's Corps, which was making a most desperate assault in the belief that this position was only occuped by raw militia. To gain this position, which was the real key point of the entire Union line (as Meade, Warren, Longstreet and many others have always stated), was the object of this great flanking movement. Once the Round Tops were captured, and some batteries placed there, our entire line could have been enfiladed and swept clear to the town-the line taken in reverse-our battle lines doubled back, and all of the many trains and reserve batteries parked in the back area between Culp's Hill and the Baltimore Pike, and our left flank would have been in great danger of being stampeded and captured. It was a most desperate fight which fell almost entirely on this brigade 
(Vincent's) and this regiment. After exhausting their ammunition, the gallant men replenished by snatching cartridges from the boxes of their fallen comrades, and those from the enemy dead. At one time the colors were well within the enemy's lines and the fighting circled about the color-bearer who, planting the staff in the ground and picking up a rifle, defended his flag with bayonet and butt of his piece. All the corporals and one sergeant of the color company (commanded by Lieut. Holman Melcher, afterwards Mayor of the "Forest City") were killed or wounded-only two of the color guard remaining unhurt. Col. Chamberlain was hit twice-a rebel Colonel, selecting him out of his command, advanced upon him with revolver in one hand and sword in the other; firing the pistol at him with one hand, he slashed at him with his sword. Two charges were made; rifles were clubbed, and then with fists and rocks, the Confederates were driven way back through the woods and practically to their own lines. Many prisoners were taken by this magnificent regiment, reported to be from 450 to 460 -more than the Twentieth Maine numbered-as they aggregated but 360 on that day. Over 100 wounded prisoners were taken besides-with two field officers and several line officers and one staff officer of Gen. Law's (commanding the brigade) own staff.

The writer, when picketing in that death strewn area the next night, and before the wounded or dead had been removed, saw many bodies extending almost to "Devil's Den," whose heads had been crushed by rocks in the savage and bloody hand to hand combat on that fateful day among the scrub oaks and cedars of that then wild gorge where the Twentieth Maine had followed up the retreat of the enemy.

General Chamberlain was desperately wounded at Petersburg; was made a Brigadier-General on the field by General Grant, and he had the honor, with his di- 
vision, including his old regiment, the Twentieth Maine, to receive the surrender of the Confederate Army at Appomattox Court House. The enemy dead in this bloody fight for the Round Tops were of the Fifteenth and Forty-seventh Alabama and the Fourth and Fifth Texas. No other attempt was made to attack this end of the line, which was held by that gallant regiment like a vise to the end.

The Alabamians and Texans were no match for the double-fisted lumber jacks of the Maine forests, nor the sailor boys and "tar bucket" huskies of the old Pine Tree State, in a hand to hand mêlée and mix-up. It took the young West Point colonel, after many trials, tribulations and heart burnings, some months to point out the way to the Art and Science of War, but it remained for that calm, quiet, gray-eyed native son (later Governor of Maine and President of Bowdoin College) who knew the scrapping qualities of his "Dirigo" boys to lead up to and over the rugged slopes of the Round Tops where they could practise the true "Art of Fighting" without too much tactical "bunk" and maneuvering. There was the fight. There was no time to study or discuss the "Art and Science." They were the men who knew how to fight, and so they "went to it," and they needed no books. In that battle, so General Chamberlain reported, "All of the 'absent sick' went into the fight"- -he dismissed his 'pioneers' and the 'provost guard' which had charge of the men under arrest-all of whom rushed in, 'locked horns,' and did most gallant service." (See "Maine at Gettysburg.")

\section{The Fighting Qualities of the Fighting Generals and} the Fighting Men Won the Civil War

It was not the Art and Science of War but the dogged pertinacity, the infinite patience and dauntless courage under almost disheartening conditions, of a Grant- 
the incessant hammering, rugged perseverance, fixed determination, common sense and brilliant action of a Sherman-the unconquerable purpose and matchless, inflexible spirit and bravery of the "Rock of Chickamauga," George H. Thomas-the bulldog grip and tireless fighting of a little "Phil" Sheridan-all of whom knew the "Art of Fighting," that won the sanguinary battles of those four long years of Civil War. If anybody saw any complicated tactical maneuvering or any grand strategy displayed on those murderous and bloody battlefields, it must have been by one from the rear of the battle lines-some artist, photographer or newspaper correspondent,- - for the writer did not. It was generally the soldiers who won out, fighting under the incomparable leadership of those magnificent line officers who had thoroughly learned the game of war, as it was actually played and not as newspaper correspondents, space writers, and artists thought it ought to be played, and when those fighting leaders were down on the line-not at some "rest area"-the leading was done without any "bunk," "lugs" or "frills." The courage and devotion of the fighters in the Army of the Potomac was sublime, and amid all and in spite of all the reckless and stupid generalship displayed its sadly torn ranks stood firm and undaunted when those leaders who knew and practiced the "Art of Fighting" finally brought it to the last goal at Appomattox.

It was those men of quick, unerring judgment and rapid-fire action, combined with rare, good, horse sense that made success certain in the campaigns and battles, of both the Civil and World Wars, and not the men of uncertain, plodding mentality and halting, hesitating, indecisive action, with minds always painfully centered on what the books had taught them and always unwilling to receive advice from those about them who had had plenty of battle experience. 
Grant, while he was generally invisible to the men, was directing and his presence was always known and felt. Sherman, while he was always visible, was an inspiring force. Thomas, the silent, grim soldier, was ever a tower of strength. While Sheridan, the incarnation of battle, was the game cock that never wavered.

These combined all of the fundamentals-courage, devotion, loyalty and skill in the leading and handling of men in battle, which few men can do-and all without the telegraph, the telephone, the typewriter, the bombing airplane, the motor truck, first aid, elaborate base hospitals, rest areas for exhausted divisions, comfortable billets for reserves, Red Cross, and almost countless auxiliaries or accessories which contributed so materially to our gallant fighters in the A. E. F. during the late World War.

\section{Universal Military Training Necessary for Better Citizenship}

The next best, and perhaps the only way now left open for the quick and most certain method to develop a new bunch of real American fighters for our future army personnel-now that our "tar bucket night," "North End," "Dock-Square," and "Bunker Hill" fighters have become like the "dodo," an extinct species, and the other methods of developing them have practically disappeared-while a genuine pussy-footed race of pacifists ("No-more-wars" patriots) have taken their places and are apparently now preponderating; also to avoid or gradually eliminate a breed or race of mongrels, hybrids and near-sighted, knock-kneed, stoop-shouldered, flat-chested lot of "cakeeaters," and shambling "molly-coddles," from thirty per cent to forty per cent of whom have got to be culled out of any would-be organized army and dumped into the scrap heap-in case of any future and sudden war being forced upon us. This plan is to adopt now, bending all 
of our energies to the task, and without any further delay, argument or discussion, a universal military training for the United States as an essential part of our national school system or curriculum, and to include all boys from twelve to eighteen years of age- the youngest boys, from twelve to fourteen, to have a thorough military "setting up" (Military calisthenics and physical exercises), all to be organized into companies and battalions for marching, camping and all other military purposes; the older boys to be drilled under arms a certain number of hours each week so that it would not in any way interfere with their regular studies-and all to be placed in training camps for at least thirty days every summer, there to be taught a thorough use of the rifle and to be given the maximum practice on the target range. A few marches, short at first, and field maneuvers could be given them to teach self-reliance, camp and campaign methods of bivouacking, etc., and to harden their muscles. The physical training of the youth of America, whether school athletics or military setting-up exercises are employed, should be participated in by all if we wish to see the growing boy changed from the present narrow, stoop-shouldered, flatchested scuffing specimen, now seen in the streets, to an erect, alert, manly looking lad. Instead of football elevens and baseball nines-a select few with crowds of admiring, screaming, hysterical fans and loud, clacking backers - let us have something that includes the entire student body so that such training will put every school boy in the healthy bodily state to permit the very top-notch functioning of his mental powers. In but few of the public schools of this country is such a training shown today, all of which may and does account for many of the defectives which any man who has been trained as a soldier may see in his daily walks, and who, when war may again be forced upon us, are bound to be thrown into the discard heap as non-effectives and military derelicts. 
This training, rather than inculcating the spirit of militarism-as our white-livered pacifists declare would be the result-or fostering a war-like spirit, would make for a better citizenship which, in a few years, would be most astounding in its results, and would be universally praised by all, especially the mothers, who would like to see her "George" a straight, upright, manly looking boy rather than a weak, puling derelict without shape, force, decision, ambition or direction. It would be a business asset, besides. No business man likes to see, much less to employ, a sloppy, ill-shaped, dull-faced, shuffling boy who, scuffing and with feet wide apart, comes into the presence of an alert man, and in answer to his questions invariably answers "Yep!" But, he will more likely employ the alert lad who, well "set-up," erect and with shoulders back, with good carriage and manly presence, and heels together, answers all questions with a respectful and snappy "Yes, Sir!" or "No, sir !"*

To understand or to have a full appreciation of the benefits conferred upon a young boy, it is well known by experience that not only do they readily acquire an erect and soldierly bearing and easy carriage, and have been taught how to command and execute as well as to develop and quicken all of their perceptions and mental processes, but, under a form of government like ours-which seems to have a most rabid suspicion and dislike for any army or navy whatever-and while we are vainly endeavoring to digest and assimilate in this great "melting pot" of ours, which fails to melt, merely coming to a boil, countless swarms of children of foreign-born parents in our public schools; this military training is the greatest factor-and the writer declares this from a full knowledge and a wide experience in this work-for the speedy Americanization of the same, as well as being the great-

*Note-Perhaps this mental picture and its application to some of the boys of the present generation-the so-called "Willie-Boys," "Johnnies" and "Cake-Eaters" may be clearly recognized. 
est leveler known. While it is assumed that all are not born "free and equal," this work, well co-ordinated in the public schools, affords all-rich and poor, black and white-conditions of society an equal opportunity for a rapid physical and mental development, and they all enjoy it after they begin to know and see its real benefits. They would all surely enjoy and immensely benefit by the camp experience-care being taken to make it attractive and not too severe or too sudden as was the case in some of our large training cantonments.

The lessons of obedience and discipline (now that it is being observed that young people are becoming lawless and getting away from the old-fashioned home training and parental control) which boys have learned through this training and who have carried it into their business careers, have never been forgotten. These lessons are almost incalculable. The friendships formed during their shoulder-to-shoulder service, as has been shown at West Point and Annapolis, are always more durable than could ever have resulted from mere college or university association. Youth, even from a very tender age, should be taught to know, respect and obey the law. At present they are not so taught. Military training inculcates discipline through prompt obedience to lawful orders or commands, and both should be and are potent factors in the restoration of parental authority and control which, as everybody knows, instead of being a prime essential in the rightful training of future citizens has, for a long time, been a decidedly neglected function. Whither are we drifting? All this would seem to need no further discussion or argument to convince anyone except an incorrigible pacifist.

When the United States became involved in the World War, the men who had received such training in the schools of this country, especially those of the Boston High Schools, were immediately available and rendered invaluable aid, especially as officers and instructors in 
the large training camps. Once established, and the benefits which have been pointed out could be seen, the steady growth of such a universal military training throughout the United States would be a matter for public felicitation, and besides, we would no longer need to worry over the bugaboo of non-preparedness, for with arms in the reserve supply depots and millions of young men who had had this preparation-the preparation for better citizenship_-even though all might then be engaged in civil pursuits, they would be ready at the call, while our standing or regular army need never be a large one. All this at a ridiculously low cost, the boys furnishing their own uniforms as a part of their school dress. They would be simply furnished with their subsistence, while serving a thirty-day camp tour, and their camp outfit_blankets, marching kit, etc. All of the details could be worked out by our General Staff. There are now more than six thousand schoolboys undergoing this training-all except the thirty-day camp tour-in the Boston public schools, under one of the most competent military instructors in the country, Colonel Charles A. Ranlett. He was at West Point for two years1894-1896-not being able to complete his course on account of some slight physical defect, which thus far has never debarred him from military service; he was at the training camp at Plattsburg; went over to France as a major (temporary lieutenant-colonel) ; was on General Bullard's staff and as an all-around, efficient trainer and military instructor of these young boys has, probably, no superior in the country.

The Boston people have, for over fifty years, always fully appreciated the value of this training for their boys; have a true pride in it and it would be very difficult, if not an absolute impossibility, to now abolish it from their public schools. Many of the young, superb officers of the famous Twenty-sixth ("Yankee") Division of fighters 
came from these Boston school organizations.* Such a scheme of universal military training for all of the youth of this nation-so imperfectly and briefly outlined would, it must be clear, obviate the necessity for a periodical hysteria and crazy rush for preparedness whenever war shall have overtaken us or, rather whenever we shall have been kicked into it. A vain, almost criminal, attempt to raise a million men over night for war-a la William J. Bryan-and putting them improperly trained into battle for cannon fodder.

\section{German Tactics and Strategy for Our Army}

But now, in the face of our experience and the necessity for re-establishing ourselves again, not as a military nation but as a country in a state of preparedness for our future safety, comes this most amazing announcement in the public press, which follows: that hereafter we, as a nation, are to learn not only the Art and Science of War, but the Art of Fighting from a Ludendorff and a Hindenburg and the methods of the German General Staff in the art of supply, etc.

(Washington Times, Thursday, June 8, 1922.) "U. S. to Learn Strategy of Ludendorff. Military Secrets of High Command Now Studied by American Officers. 'Military secrets of the German High Command during the World War have been bared to officers of the United States army for use in future wars, it was learned on highest authority today. Representatives of the War Plans Division, American general staff, are now in Berlin making an exhaustive study of hitherto closely guarded records of the German war office.

*Note-For confirmation of this and as a further evidence of the pressing need and great value of such a training of our boys in the public schools for better citizenship and to teach them discipline, law and order and Americanization attention is called to the report of the Chamber of Commerce of Cleveland, Ohio, upon the resolution of the Cleveland Board of Education asking for the same, a transcript of which may be found in the Army and Navy Journal of September 9, 1922, page 34 . 
" American army officers of the next war will have the benefit of a thorough knowledge of the organization, training and tactics of the Kaiser's armies. The strategies of Ludendorff and Hindenburg in their desperate campaigns to save the Fatherland, it was learned, will probably form the basis of text books in the United States Army War College.

" 'Lieut. Col. Walter Krueger, of the War Plans Division, U. S. A., is in charge of the work now being carried on in Berlin. Complete reports of his researches among the archives of the German war office are being forwarded to the War College here, where the material is in process of arrangement for presentation in various sources of instruction provided for high ranking officers of the American army.

"The subject matter of these reports first will be presented to American officers in the form of lectures. Later these lectures probably will be produced in book form, with commentaries by American military experts upon the manner in which their lessons may be applied to the American army.

"American experts are frank to admit there is much to be learned of the military science from study of the records of the German staff. Particular attention is being paid to the German supply system, which is regarded by military authorities as probably the most complete and efficient ever devised." "

In war there are certain factors which are always constant. One of these factors, as has already been stated, is the "Art of Fighting." It matters little whether the principles governing the Art and Science of War for that period-1861 to 1865 -did, or did not apply during the late World War, or could apply now or in the future, it is certainly manifest that the Art of Fighting did apply, and it applies now and ever will in future wars-it is a constant factor; it never dies-and it is quite as certain that we Americans can never learn that art from the Germans. This was clearly shown when our well-trained American divisions, after intensively training our men here in every detail of trench fighting according to the methods which the Germans had, for a purpose, initiated and vigorously pursued for nearly three years-and later, when our men reached the French and British training areas in 
France, we chose to change our system or Art of Fighting and broke through the "Hindenburg Line," got the Germans out in the open and then never stopped until the very best of the Hun shock troops had been thoroughly taught, not the Art and Science of War, but the true American "Art of Fighting." Any of our American division commanders, with whom that Art of Fighting was either not inherent or who had failed to assiduously cultivate it during some perod of his life, whether a graduate of West Point or otherwise, was duly "scrapped" or "canned" and replaced by fighters. It was amazing how many there were. Some of them did not measure up to a live, wide-awake, scrapping corporal of the Fourth Cavalry in the old days of Indian Campaigning, simply because they did not have the fighting spirit, nor could they have acquired it by any amount of education; moreover, they lacked the initiative, force or push, military alertness and stickto-it quality necessary to make a good, active soldier for field or battle work. It was little short of a crime to place them in command of men who had been trained for fighters and when battle was impending.

To begin now and feed our young American officers and military students at our War College, even with the remotest principles of the German methods, either by applying them to the Art and Science of War or the Art of Fighting, especially the latter, seems to the writer not only an absolute absurdity and a travesty, but a ridiculous farce and almost unpardonable insult to the real intelligence of our American youth, who, if they had never been taught any other one thing in their lives, especially in the profession of arms-ever since the writer was old enough to know anything about the military traditions of our army-it was to have complete faith that there was never a full-bred-red-blooded American living, who had been properly trained, who could not whip the paunch off any German who ever 
lived of equal years, height, weight, and condition of health. The writer has trained Americans, Irish and Irish-Americans, Germans and German-Americans, Italians and Italian-Americans, Spanish and SpanishAmericans, Russians and Russian-Americans, English, Canadians, French and French-Americans, Poles and Mexicans, and taking every thing equal, he never saw a full blooded and thoroughly trained American soldier -once he could be properly controlled and disciplined - who couldn't whip any of his comrades of other nationalities in a fair, stand-up fight. A German made a very good, clean, smart and tractable barrack soldier, and was more amenable to discipline than the American, due, possibly, to a more careful or strict home training. But as to his scrapping qualities and fighting stamina the writer never saw him stand up with a husky, two-fisted American either in barracks or in the field. He generally excelled in, or did his fighting through bluster, brag, bluff and a badger-like noise-such as one generally heard in a German beer garden-and, as was demonstrated from 1914 to 1918, he chose to do most of his fighting under ground. The writer saw an entire division of Germans, who, at that period of the Civil War (18621863) were said to be fairly representative types of the trained and disciplined armies of Germany, run out of two great battles of that war-Chancellorsville and Gettysburg-and jeopardize the safety of the Union army on both occasions. They were absolutely panic stricken, demoralized and disorganized, with the fight all out of them. No herd of buffalo or cattle were ever more panic stricken. Then why do we want our young officers pointed out any of the methods which either Hindenburg or Ludendorff employed during that period of atrocious carnage and double-faced, crooked warfare, when poison gas, liquid fire, poisoned wells, and all sorts of low down, underhand tricks and terrorizing methods were employed by a bunch of red- 
handed Huns and savage beasts and vandals? Why do we want any such accursed methods brought into our American War College, such as were never known or heard of among our American fighters since our earliest Colonial history, and from the days of Daniel Boone down to our Civil War?

There is nothing in the Art of Fighting or the methods, as clearly demonstrated by any or all of our best Civil War or World War fighters and leaders, that could be learned from either a Hindenburg or a Ludendorff, with their overpowering and bull-like clumsy rushes of shock troops. Of course the field tactics of our armies which had been fought during our Civil War in mass formation had to be changed, and Gen. Emory Upton was quick to observe this and was the first officer of our army to make that change. We now possess the most elastic system of tactics in the world. Just as soon as the German trench and underground, gopher-hole method had to be changed, and that was just as soon as the trained Twenty-seventh and Thirtieth Divisions of American troops broke the Hindenburg line-then was the fighting superiority and initiative of our intelligent American boys seen and felt. After all, the final battles will always have to be fought on top of ground. There are no troops in the world better fitted by initiative and dash than American troops for open, abovethe-ground-field-fighting, and it would be a folly and a shame to now retrograde and take up the study of any of the German goose-step-barrack-soldier systems or underground, gopher-hole methods of defense. Let us stick close to what we accomplished in that World War under the inspiration of Pershing, Liggett, Bullard, Summerall, Dickman, Lewis (William), Hahn, Lejeune, O'Ryan, Harbord, Reed, Neville, Alexander, Ely, McAlexander, Menoher, Smedley Butler, and a host of other American fighters who, having once got the German guards on the run, kept them running. If wars in the 
future are to be fought by the aid of auxiliaries such as tanks, bombing airplanes, grenades, and the use of gases, those units can have special training, but let us confine our studies closely to our own methods of strictly infantry line fighting (the more elastic the better), which have always been successful after we once took the pace and got on to our stride. Our young officers, especially the graduates of West Point, need to go to no German barbarians for instruction or to gain any inspiration from them in order to learn the "Art of Fighting." The history of this republic ever since its formation affords ample proof that when we relied upon the knowledge and genius of our own fighters we have always been uniformly successful. The trouble has always been to find the real fighters, as distinguished from the fellows who had assiduously studied and knew the Art and Science of War and implicitly believed that it stood for or spelled-fighting. The experience of our soldiers in past wars of this country has been, and should be in the future, of the greatest value to them. Let us not turn to the dark pages of Germany's wars for any enlightenment to the brave fighters of America. The whole scheme looks like a piece of carefully worked up propaganda.

General Sheridan states in his personal memoirs, Vol. II, page 451-2, that as an observer in the Franco-Prussian War he saw "no new military principles developed, whether of strategy or grand tactics. He might have added, or in the "Art of Fighting."

He leaves to "conjecture" how either the French or German armies "would have got along with our bottomless roads from the Wilderness to Petersburg and from Chattanooga to Atlanta and the sea."

$\mathrm{He}$ is also said to have privately stated to a friendbut not for publication-that with both Union and Confederate veteran armies-just as they were in 1865-he could have made "short work" of and "whipped out of 
their boots" both the French and Germans which he saw engaged in several severe battles and at close range.

There were certainly no new principles during the late world war as applied to the real "Art of Fighting" that would differ in the slightest degree from that which has been noted in every war in which an American army has been engaged. When the lines closed in the best fighters won out. All else was in the dark and under cover.

\section{Balck's "The Development of Tactics-World War"}

To show how prone we are to turn to foreign countries for our strategy and tactics, our uniforms, our equipments-even to the latest craze of changing our old American cowboy seat in the saddle, with long stirrups, and the men retaining their erect positions, but regulating them with the motions of their horse-this has all given way to the "posting," "roaching" or rise in the saddle, the men leaning in the most ungraceful attitudes which, in the days of the writer's cavalry service, was not only considered "bad form" and un-American, but laughed and jeered at as poor equitation and something to be immediately remedied in a trooper who practiced it, as the strongest proof of poor riding.

And now there comes to the writer from the Book Department, General Service Schools at Fort Leavenworth, an announcement that it has acquired the American rights of translation of a German book by one Balck of the defunct German army on "The Development of Tactics-World War," who, according to Colonel H. A. Drum, Assistant Commandant, "discusses authoritatively the German tactical viewpoint and also endeavors to apply the German war experiences to future wars." In the same breath and in spite of this announcement, and in connection with Colonel Drum's comments, it is urged upon Americans "with the idea of furnishing military 
readers of this country with a book of real value." While Colonel Drum states that the book is "extremely interesting and instructive to military students" "American students of this book are cautioned to avoid blind acceptance of all teachings embodied therein." *** "National and racial characteristics are fundamental considerations in the adoption of tactical doctrines. The war on the western front does not represent the ideals, methods and objectives of military leaders who believe and advocate the principles underlying open warfare situations and the supremacy of the human element over the mechanical device."

After this carefully worded opinion, comment and bit of advice, with which the writer most cordially agrees, as it all comes within the scope of this paper, Colonel Drum then adds, "With such caution in mind, the American military student will derive many benefits from a careful study of this book." And that is just where the writer, who has had plenty of experience, both in the Civil War and in Indian wars, most radically disagrees with such conclusions.

If this mixed caution and advice is not paradoxical it is certainly anomalous and enigmatical.

In the name of common sense of what "real value," or how can the "American military student derive many benefits from a careful study" of that translated book on German tactics of that war on the western front if it does not represent the "ideals, methods and objectives of American military leaders?" etc., and by this it is assumed that it means the leaders or "fighters" who, emulating the example of Pershing, Liggett, Bullard, Dickman, Summerall, and the other army and corps commanders who have already been cited, are to become the leaders of American soldiers in future wars. Then, why not can all of this German propaganda, get back to our own fighting systems and methods by which we cleaned up the German strategists and tactical sharps and "stick 
to our own last," letting our officers continue to study their own "Development of Tactics-World War." If we could learn nothing from them-the Germans-during that war, we can certainly learn nothing now or in the future except atrocious methods and brutal savagery. Too many of our young officers have become obsessed with and too much stress has been laid upon the value of tactics, and the ability to execute tactical maneuvers upon a field of battle. After the first deployment forward and the firing has begun, no tactical formations can be maintained, or only for a short period, and for reasons heretofore given. So the main points in maintaining any semblance of battle line formations is to observe as simple tactics as possible, and as long as practicable, and then rely upon the coolness, discipline, fighting spirit and good leadership of the line officers with morale unimpaired, and keep up the fighting. There are no better examples of no tactics, but fine leadership known in the history of the World War than in the cases of Sergeants Alvin York and Woodfill, both Medal of Honor men and recipients of many foreign decorations. Yet the one was a Tennessee mountaineer while the other was no tactician - and both of them would have probably been found deficient in a class at West Point had they been examined and asked how their gallant deeds were tactically accomplished when they won their decorations and to explain to the class the tactical movements. It is extremely doubtful if either of them could have drilled a company of infantry tactically or to the satisfaction of a newly graduated cadet at West Point. They were simply endowed with plenty of common sense, but more than that, with the true fighting spirit or "Art of Fighting," which always gets men there if they want to fight and do not stop to work out all of the tactical combinations which the Art and Science of War teaches-lays down-but does not explain how it shall all be done or worked out when in a real wild cat battle, and when a 
man's true fighting sense is the real factor which has got to be brought into full play. Would it not be far better for us to teach our young officers and men more of our American initiative, more of the tactics that fit into our "racial characteristics" and our "systems and methods" which we have always employed, especially in view of the comments of the heads of the Service Schools at Fort Leavenworth? Why attempt to convert our army into a purely student body in an effort to saturate them with books-and especially German books-dealing with the "Art and Science of War," instead of spending that time in developing their initiative and fighting sense, and in a practical application-not of German methodsbut of American world war experiences as worked out in France by our own American fighters, and on our own battlefields for four long, weary years of civil war?

The average war college and service school student officer seems to have become fed up with the idea that we need in our army some other system than our ownthe German for instance-to develop it into a more highly organized and perfect fighting machine, using the argument that because we have no adequate or well-defined system, and because Congress will not favor or support whatever plan or system which the General Staff has so often recommended, it becomes necessary to adopt some other, and why not the German?

That, in the judgment of the writer, is neither a good nor a sufficient reason, nor is it a logical one. If Congress does not nor will not approve of or support the American system, such as it now is, after being engaged in the World War, much less would it recognize, consent to adopt, or suppport for a moment any other, especially the German, because, under our form of government that would smack of militarism, pure and simple. Congress will not even approve of the plan-so often and so highly recommended by the general staff and by General Pershing himself-which would place us in a state of preparedness in the quickest possible way and with the 
least possible expense, and which has been so strongly urged in this paper-universal military training in the public schools as a part of our national education. If so, then it behooves us to stick closely to what we have already demonstrated as being the best we can get and which, when in war we came in contact with Germany's highly organized army - and it was fully tested out from Chateau-Thierry and the Meuse-Argonne drive to Sedan - proved to be the best in the world.

It is true that we are not a military nation and at present we have no expectations of becoming one, but we have descended from a long line of fighting ancestors; can very soon develop their (those ancestors') fighting spirit, and have fully demonstrated many times in our history that with our initiative and capacity for fighting, even with no military policy and a system heavily weighted down at present with prejudice and opposition by pacifists, it is better to "stick to our last" and not turn to other nations, especially Germany, to bring upon us more prejudice and still more unreasonable opposition. That would certainly be our last straw, our last remaining hope of ever expecting to come back to "our own"-our individuality and inherent fighting spirit as a nation.

Any efforts to feed up or saturate our young officers with a German military spirit or with their war organization and plans or to apply the same to our system would meet with a storm of disfavor. "We should not abandon what we have because we cannot have what we want."

It is not so very long since that we heard from the halls of Congress-and the writer distinctly recalls itthat both West Point and Annapolis, far from being the democratic schools which they should be, and which the American people intended them to be, were "hot beds of aristocracy." 
They would not tolerate turning those two academies into schools whose graduates were inclined to imbibe the German Art and Science of War, or even their highly organized plans and systems which the German General Staff and "High Command" used in conducting war which-because, for a while in a campaign of barbarity and atrocious terrorism, got a tight hold and sank into the brains of the world-now bids fair to communicate its virus to our War College and Service Schools, and through them to the entire army, committing us, in the writer's judgment, to a most fatal error. Should such a step be taken it will practically be an acknowledgment that neither West Point, the War College nor the Service Schools are capable of solving our own American war problems and our American "Art of Fighting in the American way, and sooner or later there will be a howl from Congress and the people to abolish not only West Point but perhaps our entire military establishment. The army has been pretty well "shot to pieces" as it is.

\section{Practical Emergency Tactics at Gettysburg}

At Gettysburg the volunteer regiment in which the writer served was about to be flanked. A portion of Hood's Confederate Division, Longstreet's Corps, was being marched obliquely along or across its front and around its right. No orders could be heard in the wild din and uproar of the battle at that moment. The rifle fire and cannonading was incessant. Word was passed along the line to "Change front to rear by the right flank!" Hardee's Tactics accurately prescribed the movement, which under most favorable conditions was an intricate one. It was a physical impossibility to execute it as laid down in that wonderful book (We were in woods with large boulders scattered about), so common sense stepped in and took its place. The command was given "About face!" We marched to the rear, carrying 
all of our wounded on blankets fastened to riflesthrough "Rose's Woods" into the big wheatfield. En route we passed through Caldwell's division of the Second Corps, marching by its flank in column obliquely to our left to extend our line and support Birney's division of the Third Corps, then hard pressed. As soon as the "Wheat Field" was reached the line was halted, faced about, the new left wing was ordered to make a right half wheel, while the former left wing was ordered to refuse its right a few paces ("right backward, march, firing!") and we were soon firing Northwest. When the movement was begun we had been firing Southwest. It was all done coolly, under a terrific fire-the veteran line officers simply steadying the disciplined men with their voices, and the men maintaining their fighting spirit, morale and guts. This brief recital is a very fair sample-in fact it is a true illustration-of how such tactical movements were executed on a battlefield under those conditions, and that kind of a fire. Furthermore no such commands as were given for the execution of that movement can be found in Hardee's or any other system of tactics. No German Tactics, written by a Balck, could disturb any combination like that, or the strategy and tactics of the two fighting sergeants-York and Woodfill-already cited. The query naturally arises, how can the almost phenomenal deeds of these two soldiers be accounted for? Will anybody contend that they were due to the daily tactical drills and long, drawn-out, intensive training that they had in the big camps prior to their departure for France and before they had had the opportunity to show the fighting stuff they were made of, the daring and cool nerve which led them, when isolated from their command and away from the eyes of their officers, to go up against machine gun nests and to paralyze their German enemies with their ready wits, adroit moves and determined, decisive action? Most assuredly it was not! 
To attempt the almost marvellous feats of these two clear-headed, double-fisted fighters would seem to have been a dare-devil, almost foolhardy act, and yet when each is considered and analyzed and placed in the light of the omissions and commissions of some of our battlefield tacticians, fed up on their book knowledge of how such affairs should be conducted by the hard-and-fast rules and cut-and-dried plans, by which they had been taught, there is a cunning, a fighting sense and balance -a battle psychology which, with the sangfroid of the brave actors, accounts in a degree, if not fully, for their most surprising success, and for which, even the Medal of Honor seems to be a very insignificant and inadequate reward.

It is true they had the opportunity (which does not come to all men in battle), afforded them for the development of all their mental and physical powers. Better than all, however, they were both all-around, quick, ready, off-hand rifle and pistol shots-the best camp training any man can possibly be given (and he cannot have too much of it) -and by off-hand is meant off the target range, with its favorable factors of heat, light, wind and enforced silence. They thus had that supreme confidence in their weapons that every well-trained sharpshooter has, and which could have been gained by no other kind of training-certainly by no long and tiresome tactical drills.

It was the same kind of confidence that we saw among our Jack Tar manhandlers in the old "Forest City" so many years ago on "Tar Bucket" nights-those young fighters who at from eighteen to twenty years of age, and as mates, with their fathers as captains, had sailed the splendid clipper ships and square riggers of that period across the seas and around the world. There is no confidence like that which comes from an all-around, practical experience with the world-one's weapons of defense-and the conscious ability to handle one's self 
in any and every emergency and crisis when danger becomes a menace to life. York and Woodfill possessed this mental poise, horse sense and balance to an eminent degree, and they had a perfect knowledge of their weapons. This consciousness of that knowledge and their physical courage did the trick. Why not train all of our men in camp in the same way? They would simply measure up in varying degrees to their mental capacities or intelligence and physical strength. We could not expect to have all of them turn out Yorks and Woodfills.

The writer is by no means advocating or urging the abolishment of tactics in field operations, or that any military organization should degenerate into mere mob fighting. Far from it; no disciplined or battle-seasoned body of men under competent officers and good leadership could ever become a mob. But he does urge the teaching of our officers and men the most elastic emergency or battle tactics, perfect fire control and the most intelligent, effective leadership. The latter is absolutely necessary. Without fighting leadership the best disciplined soldiers in the world would soon go to pieces under such conditions as the writer has attempted to describe and has actually seen, for, when the mathematical units, upon which any system of tactics absolutely depends, begin to be destroyed, then any fighting soldiers can see at once that the issue of that battle depends entirely upon the fighting spirit and unimpaired morale of the fighting units, and the ability of trained officers to hold them down to their work.

\section{Braddock's Defeat-Minute Men Fighters}

Let us go back to history for a moment. The worst jolt that these theoretical bookworm strategists and tacticians-these exponents of the Art and Science of War -ever got was from our North American Indiansthose wild Sioux, Cheyenne, Comanche, and Kiowa no- 
mads of the plains, the wiliest fighters the world ever saw-the finest light cavalry on this continent. No soldiers ever understood the "Art of Fighting" better than they, or gave our best officers, who had made such gallant records during the Civil War, so many surprises and anxious moments, before they turned their attention away from the tactics and strategy of their West Point days which they had attempted to try out on them, and gave heed to the vexed problems of Indian wars, to Indian methods and the practical, common-sense methods of fighting the wild fighters of the open with no books on military science or any fixed rules of warfare to guide them.

Nobody ever heard of or ever saw Indians fighting in anything approaching our tactical formations, and yet they had their peculiar and seemingly studied lines of advance-fan-like at first-then winging out to the front, of retreat, extension of their flanks-either one at a time or both together-of shortening their lines, etc.-all this by flash signals and other signs-and it was always quite evident that they had plenty of good leadership, as was shown in all of their battles and, as has been stated, some of our theoretical soldiers in the old days knew this to their sorrow. Their strategy was that of the wild animals of the plains and forest-the mountain lion or cougar, the wild cat, the wolf, bear and buffalo-which would never move to the rear of a passing body of men, pack-train, wagons, or cars, because to him it was an enemy. But whoever saw any better fighters? Who understood the "Art of Fighting" any better than these same wild and wily nomads of the plains?

When Braddock, contrary to Washington's advice, attempted to march his men in column along a trail infested by hostile Indians, instead of deploying them to the right and left and adopting the Indian method of fighting-or tactics, if one chooses to give it that name 
-he was shamefully defeated; he himself was killed; many of his veteran soldiers massacred and the balance driven from the field.

When Major Pitcairn and Earl Percy attempted to march their best trained British soldiers to Lexington and Concord in column along the road, the Minute men gathered-and untrained as they were, by deploying and scattering among the stone walls, fences, rocks and trees, those veteran troops were so harassed and sniped that they had to retreat in disorder and mortification for miles into Boston. What did the Indians who attacked Braddock know about tactics, or their use as we choose now to apply the term in modern warfare? What did those "Minute Men" with their squirrel rifles, flintlock pistols, scythes, pitchforks, etc., know of tactics or the Art and Science of War? They would have laughed and jeered at the idea of a drill master preparing them for those fights, and yet when the Bedford men came into the salient made by the strong stone walls at "Merriam's Corner" on the flank of Earl Percy's veteran Peninsula redcoats-the strategy was complete, and the tactics, although missing, were all that were needed to make those British veterans look like thirty cents. It was all done with no knowledge of the "Art and Science of War," but a clear interpretation of the "Art of Fighting." It was said in England about this time by some writer that "the old system of tactics is out of place, nor could the capacity of the Americans be determined by any rule of war. They will long shun an open field; every thicket will be an ambuscade of partisans, every stone wall a hiding place for sharpshooters; every swamp a fortress, the boundless woods an impracticable barrier." 


\section{Too Much Training-Sham of Sham Battles}

After a certain period of training in camp, any more training for the men or study and book bunk for the officers gets them nowhere, and wears on their nerves. What they need then is to be put into battle and under fighting leaders-field and line officers-who know the true "Art of Fighting," and to be given the real battlesense and balance, without which the best troops in the world will "stall." Once well led in battle they will soon come into their own and take the pace, after which they will need no more battle training.

A prolonged period in camp in being prepared, trained and drilled for battle-when war is imminent or has already been declared-without being given the opportunity to participate in one, simply impairs the morale, and dulls the fighting edge of the men, making it more difficult for their officers to maintain or restore the esprit de corps, to arouse the initiative, to animate them with any enthusiasm or to give them the true battle spirit. Nothing but cold, inclement weather, the need of shelter from rain, hail, sleet, snow-and impassable condition of the roads should keep soldiers once trained and disciplined for battle long in camp. After they have once been in battle, all the instruction, intensive training, and-to them-distasteful tactical drills in the world will avail them nothing. It is simply a waste of time and misspent energy. All they need then is to be kept hard and in good marching and fighting condition and be supplied with the best of line fighting leaders in whom they can implicitly trust in an emergency. The writer has always observed that nearly all failures on a battle-field came more from lack of leadership and a stupid, idiotic effort at tactical maneuvers, than from any failure to make the ordinary strategical or tactical movements and combinations planned in advance. When engaged in battle problems, 
training maneuvers and sham battles, if the latter seem necessary to their instructors, their officers should always give their men a talk on "The shams of sham battles," and always impress upon them the fact that while this sort of faking may be a factor with a certain element of value to men in training-and to officers whose commands have been limited to small units-many of these tactical and sham battle maneuvers over certain terrain could never be executed in actual battle, and then give them the reasons, based upon sanity and common sense, instead of permitting them to remain in ignorance of the same, explaining to them in detail the whys and wherefores for such idiotic assumptions of power after the whirlpool of battle may have broken up all tactical formations and disorganized the mathematical units to a point where they must be dependent on the line scrappers at any one particular place of battle contact. These are battle perceptions based upon practical experience. Such a talk would be particularly illuminating, and would, in the judgment of the writer, be not only the right kind of instruction and of immense and lasting value to both officers and men, but is the only kind of practical instruction of real benefit in battle problems which is calculated to teach them the utter impossibilities and fallacies, or false principles, and the wicked waste of time involved in many of such useless theoretical maneuvers and shams.

When the lines approach or are about to come in contact (there were at least a dozen places at Gettysburg from Culp's Hill to the Round Tops where they met in close combat), then all tactical commands are non-effective, practically useless even with the best disciplined army, and were never employed. It was a death grapple. It was the men's fight-then led by the fighting line officers-the leaders in every scrap of that nature-to give men heart and keep up their courage, 
and to pull them through to victory. No tactical orders could be heard in such a rough and tumble combat or a mix-up, and the units were too much broken up.

This has always been a very difficult condition to explain practically to the average student officer who has been fed up on-and is thinking of his tactics when he should go into a battle, or any action other than a sham encounter, and get into close quarters with an enemy. There are no tactics, son; the only thing then is to "butt in," using rifle, pistol, fists or anything else that might come handy (the Twentieth Maine used rocks in the gorge between the Round Tops) just as Sergeants York and Woodfill did, and simply show the world what kind of fighting stuff you are possessed of and how you can use the training and discipline with which you have been loaded for weeks, perhaps months in camp, to the best advantage, and what kind of material you are made of to command the fighters who have been rylaced in your care to handle.

Any tactical formation or orderly advance of battle lines where the terrain is diffcult for maneuvering, or over rough and difficult ground, through forests, or woods with tangled underbrush and chaparral, is practically impossible. The formations soon become broken up and lines disorganized and intermingled, especially in the face of an incessant and withering rifle and canister, shrapnel or machine-gun fire. Numerous instances of this lack of co-ordination under such conditions were shown during our Civil War, among them the attack on Marye's Heights, Fredericksburg, Va., December 13, 1862; Stonewall Jackson's attack on the Union right flank at Chancellorsville, Va., May 2, 1863 ; Pickett's charge at Gettysburg, July 3, 1863; Hancock's attacks on the Confederate Salient (McCool House), now termed in war literature the "Bloody Angle," at Spottsylvania Court House, Va., May 12, 1864-all to demonstrate the fallacy of attempting to closely adhere to 
tactical maneuvers during even the best organized and elaborately planned attacks along the front of an army.

Just here is where the true leadership and best battle experience of our trained line officers come in. In sham battles there are no casualties, nobody is being killed or wounded, nobody is being knocked out of the ranks, the guides and file closers are able to keep in their proper places, the fours are intact, the lines are not being disturbed or disarranged,-consequently the tactical formations based upon mathematical units can almost always be fairly maintained in the advance and up to the moment of actual contact, or when the umpire announces his decison.

It has always been a very great source of self-congratulation to the writer, and he is more than glad that he had the privilege-before going to West Point - of serving as a private soldier in a veteran fighting volunteer regiment during our great Civil War, and was in some of its greatest campaigns and battles. The value of that kind of service to any young man (the writer was a mere boy), though it was hard, with its almost crushing grind of hardships, privations and sacrifices, and almost like wading "through the valley of the shadow of death," - a veritable "bloody sweat" of battle-it was to place him near to the real thing-the real hell of battle, with all of its horrors, its everchanging phases and conditions, both in success and defeat, and all that which affects or tests out the true spirit and morale of the thoroughly trained and disciplined soldier, but particularly, the new soldier. He could, therefore, after entering the Military Academy, all the more readily grasp and measure up the theoretical end of war, its "Art and Science," as it was taught at West Point, and as it was given him by men who, although they had never been in battle, and had never seen one, had carefully read up on them, and in lessons and lectures strove to impress it upon us-we, who could "give 
them cards and spades" on the "Art of Fighting," or anything measured out by them from books written by authors who dwelt not on facts and the practical results of battles, but upon the "ifs," "ands," "buts," "possibilities," "probabilities," and forced conclusions which governed them, so that they could fit into the theories of the "cut and dried" professional tactical and strategical know-it-all soldier.

It has given the writer an opportunity of showing up or exposing some of these non-battle-bookworm-soldiers' fallacies regarding the maneuvers and tactical combinations in a real wild-cat battle mix-up, and their student ideas on sham battles, war games, peace field maneuvers, etc., as a prelude to real battles where somebody is getting killed or wounded and tactical units are being disintegrated, destroyed and thus rendered useless.

The only reason ever given to the writer for all of this never-ceasing, intensive training, in time of war, and to prepare men as soon as possible for quick and effective battle service, was by the late Colonel George H. Sands, who, as a member of the General Staff, War College division, prepared the camp schedules for instruction at all training areas.

He said that on account of insufficient transportation to get the men overseas soon enough, so that they could be assigned to the French and British training areas, it was thought necessary, in order to keep the men employed, to go over the same work day after day, even if it did involve much useless repetition. That was a logical reason. But many of the camp instructors always insisted that it was all necessary for their discipline and to better prepare them for battle. That was not a good or a logical reason but, on the contrary, it was mere bunk. It not only got those men nowhere, but it impaired their morale, lessened their aggressiveness and weakened their mental and physical powers. Moreover 
they were never enlightened or told the real reason for all of this everlasting daily grind and repetition. Men are not dumb animals and if they are known to chafe because they do not understand the reasons therefor, they should be given the necessary information in order to stabilize them and secure a more ready and willing obedience to orders, without which most men, whenever they are treated like cattle, will only perform their duties in a listless and merely perfunctory manner.

In this life we know but little at best and that little is not only altogether indefinite but generally uncertain in its application. The knowledge which we acquire is gained through opportunity, education, observation and practical experience. The first two are of little value without the third and none are of much value without the last. It is not quite certain that the first two are necessary or absolutely indispensable to the last, but if they are essential it is equally true that the last factor is absolutely necessary to make one's life useful to the world whether it be in the Arts and Sciences or in battle service in defense of one's flag and country.

Any education or instruction without observation or the opportunity of developing or applying that knowl. edge practically, gets a soldier nowhere-one must follow the other. Few soldiers are opportunists. The more education he receives without practical experience the more of an unsafe guide does he become. It is hard for him to let go of his preconceived and oftentimes false notions. Any instruction in battle problems by an inexperienced drill master, instructor or guide is apt to be false and misleading, and if based upon false premises or insufficient knowledge it may be fatal to a soldier's career unless, in the experience which necessarily follows that kind of training, he finds out for himself, before it might prove to be too late, and differentiates the right from the wrong. Such experience is generally very costly, and one of the most difficult problems and hardest 
tasks the new soldier has to encounter and overcome. The first battle may decide once and for all. It is the supreme test and to many an ambitious young general with a lack of battle knowledge and with little battle sense-no matter how brave he might be-such a test has either proved his making or his Waterloo-generally the latter.

The principal aim of some of the young drill masters in the large training camps during the World War, who had not only never been in battle or had ever seen anything approaching one except a sham battle-and who, of course, knew nothing of battle conditions-was to fit the men tactically, and to a point approaching perfection, for their work in France, regardless of whether that kind of training would fit into the game or not, and slurring over the essentials, such as perfection in the use of the rifle on the target range, or permitting it to become of second importance.

Since the foregoing was written an announcement has been made through the press that the everlasting salute which the camp instructors so assiduously and laboriously taught the men when the hysteria of the World War was at its height and which was carried to such a ridiculous farce in the Capital when the streets were crowded with embryo officers, is to be "canned" except under certain restrictions. Many of those officers before that period had scarcely ever known what a salute was or what it meant. How much time was wasted in teaching the men just how to carry their hands; how much "snap" and "pep" to put into this salute at every corner a hundred times a day. This, we old Civil War men were told, was to "discipline" them. The men were told it was for that purpose, and they all were wondering when and where they were to be taught the "Art of Fighting." Was it to be on the battlefield? The length of training had less to do with preparing them for the Art of Fighting than the kind of training they actually 
received. It also depended upon who trained them. Our men were trained long enough but they were overtrained -not instructed-by non battle-trained instructors for the most part, in the non-essentials and in mere tactical drill which made tactical mummies of them, and they were undertrained in the real essentials-the use of their weapons-and therefore were not fitted for fighters on the line. Under the first method they soon lost their individual initiative, sagged in and touched elbows with their comrades, bunched, and soon became fatal targets for concentrated machine gun fire which accounts largely for the fearful losses among men so trained.

Gen. George H. Harries, a Brigadier General of the National Guard, recently told the men of the Military Order of the World War at Atlantic City that fifty per cent of our losses were because they had not been taught how to fight. How correct this percentage is the writer has no means of knowing, but he did see at both Fort Myer and Camp Meade the men being monotonously drilled in the manual of arms day after day by the count and marched with heavy, theoretical packs in temperatures varying from $100^{\circ}$ to $109^{\circ}$ - those men who, later, were put on a battle line with a perfect knowledge of these non-essentials but without ever having taken their rifles apart or assembled them, or ever having fired their pieces on a target range unless, perhaps, they were given condemned, slow-fire ammunition, which resulted in so many serious accidents among these astounded and, as yet, untried soldiers.

Many a poor fellow came to understand what a poor asset all this "punch" and "pep" in the manual of arms, and salutes to the hundreds of officers whom he met on the streets, proved to be when he bumped up against a blithering rifle fire or a machine gun nest without a complete knowledge of his own weapons by which he might have made himself a self-reliant soldier and an efficient fighter when put to the test for quick battle 
service. Owing to some misunderstanding of just what General Harries did state and in answer to some comments and criticisms made thereon in the St. Louis Times of Friday, September 20, 1922, General Harries makes the following explanation, which is herein quoted in full in order to support and strengthen the writer's own positive and radical assertions as to the kind, quality and manner of training men for quick and effective battle service.

(The St. Louis Times, Friday, October 13, 1922.) Stupidity Killed Many in War, Says Harries. Commander-in-Chief of Veterans' Association Defends His Words Against Criticism of The Times and Explains Statements.

Chicago, Oct. 5, 1922.

Editor, The Times: In your issue of September 20 I note an editorial which suggests that 1 give my authority for the statement that 50 per cent of the men killed in the late war were killed unnecessarily, because they did not know how to fight.

My statement was that "not less than 50 per cent of those of ours who were killed in action or died of wounds were wastefully sacrificed because of inadequate training or no training at all." The minimum figures used have as their basis countless conferences with combat officers, of our own army and of the French and British forces, who commanded troops in action, and with other officers whose duty it was to observe; the service of all of whom was of such character that they might not righteously be accused of figure-juggling.

As Commander-in-Chief of the Military Order of the World War it has been my pleasurable duty to address thousands of officers during the past two years, and almost invariably making the statement you criticise. Hearers of my" summing-up of testimony range from the platoon leaders, who personally led their men, up to and including General Pershing. Not even once was there suggestion that the averment was other than conservative. At times there was protest which declared my stated minimum to be too low.

\section{Regimental Head Reports}

In another instance, in the presence of hundreds of his fellow officers, a highly capable regimental commander was statistically armed. His tale of disproportionate casualties was more nearly precise than those of other commanders, whose men suffered as 
his did, but whose observation quality was less keen than his own. His regiment had secured hardening experience during months of field training and battle experience in France.

At 9 o'clock the night before an advance in the Argonne he received 400 replacements to fill his ranks to a war strength of approximately 3,700 . Then followed four busy hours while the halfbaked or unbaked newcomers were being assigned to rifle, machinegun and mopping-up units; as complete an amalgamation as available time would permit. With morning came the advance. Two days of hard fighting ensued, followed by a careful analysis of casualties. Eighty-one per cent of the regiment's killed and wounded were of the 400 comparatively untrained men who had joined 48 hours earlier. Is it necessary for me to say that only 19 per cent of casualties occurred among the other 3,300 officers and men who had learned how to be successfully aggressive?

\section{Says Conditions are Common}

That such conditions were common is known of all men who had, by training, acquired soldierly facility and that degree of discipline which is essential in a sound military force-whether in war or in peace.

Nor were such excessive casualties confined to the enlisted personnel. Capable officers "went West" while endeavoring to correct the errors of the untried who were facing the enemies for the first time. Untrained officers departed by the same route because they had brought to the battle front little more than the book-learning memorized within the brief scholastic period of emergency education. Fine spirit there was in great abundance, but courage could not substitute for severe and prolonged instruction. Individual gallantry often lacked the support of "knowledge unto occasion at the first far view of death."

The theory that officers-battle leaders-can be created in ninety days is as ridiculously deadly as was the William Jennings Bryan doctrine that in time of need $1,000,000$ of our men would spring to arms overnight; even though they had never previously practiced springing. I recall the overnight high-jump of $\mathrm{Mr}$. Bryan to a colonelcy in the war with Spain-an opera bouffe performance-and mere political appointment which amused both Spain and the United States, not to mention the military attaches of other powers who were watching us closely.

\section{How to Win Fights}

If patriotic or pugnacious or political enthusiasm alone should be held to denote efficiency, then baseball managers might do well to select their teams from the multitude of conspicuously-vocal "bleacher" patrons. 
Your "guess" that I believe "that not much bloodshed could ensue in a combat where every soldier knew how to fight" scores a zero. The inference you draw lacks historical support. Our savage ancestors had great facility as fighters. They fought for survival and for a lot of other things they deemed desirable. The casualties suffered by the defeated army or tribe or detachment footed up 100 per cent. The crusty forefathers never left anything half done. Defeat generally meant death for the overthrown combatants and slavery for their women and children.

The French and English and Germans knew how to fight, yet there was great slaughter. But the carnage would have been infinitely greater had they done as did the people-the Government -of our own land when we flung untrained troops "raw, into battle, as we plucked them, raw from the street." The French and German armies were composed of men who were excellently trained because military service was required of every citizen or subject; in France, a truly democratic procedure, whereby each man is fitted to do his part in the defense of his own country, the period of training being sometimes three years, sometimes two years. British replacements received full 12 months of intensive training by battle-taught instructors before being sent to the lines.

\section{French Aghast}

The French soldiers were aghast at our casualty lists. The British, less demonstrative, commented quietly and regretfully. Many enemy officers, with whom I conversed after the defeated armies had returned to Germany, praised the energy of our attacks, but asked: "Where was the individual technique? Great numbers of your soldiers perished because their unbridled spirit took them into situations where they could only be defeated. Mass formations-group attacks-in the face of machine gun fire could not possibly succeed."

I could have told them, but did not, that the groups referred to were built up by soldiers who lacked discipline; who because of their greenness huddled together for that battle companionship which is the natural desire of men who have never learned to fight in extended order; who lacked that confidence in their right and left-hand comrades which comes only after months of arduous work on the drill field. Every company officer who fought in France, every stretcher-bearer, every member of a burial detail, could tell of men-wounded or dead-whose rifles had not been loaded; of others whose clips were full because they ovidently did not know how to operate the bolt; of dead and dying men in testifying heaps. That the machine guns were captured, if not with- 
drawn, is beside the question. The point is that the captures cost excessively; reasonably skilled troops would have done the work without extravagant losses.

Really, you concede the principle of my claim when you say: "Perhaps faulty ordnance or inaccurate gunfire destroys many men of that force. Probably unskillful handling of their commands by officers results in unnecessary casualties."

\section{Nation Held Responsible}

A nation that provides its army with faulty ordnance kills its soldiers "unnecessarily." A nation that waits until war breaks before starting to train the greater proportion of its officers, and thus puts most of its artillery in the hands of those who know not how to use it, must expect inaccurate gun-fire; the big guns can and did kill "unnecessarily." Unskillful troop leading is possible only to those who have been unable, in 90 days, to acquire the art of skillful leading; and there were thousands of such. Because they lacked skill, these killed "unnecessarily."

A year's time is not too much for the making of an infantry soldier-a rifleman. A skilled officer, fit to be trusted with battle command, cannot be produced in thrice the time.*

We entered the great war April 6, 1917. Twelve precious months flew by before our troop movement overseas amounted to anything in volume; a year crowded with evidence of our unreadiness and of our complete dependence upon the allies for many essential services. Half of that year flitted by before our division camps and cantonments were halfway fit for occupation; and when they were occupied it was by soldiers who, in large part, were illy-uniformed or clad in civilian garb. At night, in our own rich country, the draft recruits shivered in emergency and woolless blankets. Artillery men who had never seen a field piece sought to solve ballistic problems with the aid of dummy two-by-four bare-lumber anythings; the Congress having ignored for many years the pleadings of a far-seeing Chief of Ordnance. Except for a few samples in Washington, there wasn't a hand-grenade in the country.

We were well on our way to a lot of "unnecessary" killing; some of it being quite thoroughly accomplished in our home camps.

\footnotetext{
*The author does not agree with General Harries' statement that "A year's time is not too much for the making of an infantry soldier," unless he means that this "making" is to be done by inexperienced officers. With battle-taught officers, and with war already on, and no time to waste, if that officer does not neglect his duty-cuts out all non-essentials_and works hard, he ought to have that soldier on an infantry battle line in much less time.
} 


\section{Army and Guard Good}

The trained personnel of our regular army and National Guard wrought mightily in spite of the limitations long imposed upon them by our national legislatures, but even they were not accustomed to dealing with tidal waves. For three years they had urged and protested, and when the belated hour for action arrived the odds were tremendously against them. But they turned-to with a will, improvised much and salvaged many a life by their industry as instructors; yet not until the first anniversary of our entry into the war did the Eastward flow of divisions really start.

The reason why these unnecessary sacrifices are now being stressed is that our people shall speedily realize that what they so commonly call "the cost of war" is really the cost of unpreparedness. For 146 years we have been nationally heedless in this highly important matter.

During the War of the Revolution, Gen. Nathanael Greene said (I cannot quote him precisely because my library is not now available) that a nation which sent its sons to battle without first training them to the use of arms, was guilty of murder. That statement, and a succession of like utterances throughout a century of our history, is contained in Maj. Gen. Emory Upton's illuminating treatise on our military policy; a publication that should be read by every understanding man and woman in the United States.

Since the day of General Upton we have run true to our ancient form. So far as the public and most of their official servants-or leaders-are concerned, we have learned nothing. Each succeeding war has found us lamentably unready. And we have paid enormously more in blood and golden treasure than we would have done had we been economically wise and commonly humane. We have spent lavishly to defeat alien enemies. Temporarily, we have saved a few dollars through ill-timed pacifistic folly and, as direct consequences of that enduring short-sightedness, we have squandered prodigally the lives of our really worthwhile men. Recklessly have we slain our own. Ruthlessly have we multiplied widows and orphans.

\section{Expects Proof in Statistics}

Precise figures such as you demand are not yet available, but I am sure that when the tabulations do appear they will more than confirm my casualty statement. Long before any official statistics can be compiled I expect to have a great amount of direct testimony from combat officers of all grades. The fathers and mothers shall know what losses they may expect to suffer when war comes, 
while we are still bent upon a supineness which must inevitably result in unnecessary destruction of our own.

GEO. H. HARRIES.

It has all led up to the reluctant conclusion that any field commander, whether he is a Battalion, Regimental, Brigade, Division, Corps, or Army, who has never been under fire or never seen a battle-no matter how exceptionally efficient or able he may have been as a military student or drill instructor, is practically worthless to command those units on the assumption that his theoretical knowledge is absolutely correct as a decisive factor in handling those troops under battle conditions. Any view from the rear is misleading and erroneous-textbooks are worthless. Close contact as a soldier is not only essential as a guide but absolutely necessary as a teacher. No observer at the rear not under fire can possibly gain so intelligent a conception of how a battle is going, or what a battle means with all its changing conditions, as the man on the line in the mixup, subjected to the hell of fire, death and destruction going on all about him. All the observer's preconceived theoretical knowledge and plans of battle are at once disturbed if not entirely broken up by the inextricable confusion, roar and din he sees before and around him; and after all his years of book study, essay writing, map making, tactical drill, sham battles, war maneuvers, and umpiring, he generally is compelled to fall back on his sound, common sense if he has not parted with it, and change in an instant all his student ideas of battle. There is no time to lose; he must act instantly or he is gone. "An army of sheep commanded by lions is better than an army of lions commanded by sheep." This is an old but apt saying when applied to the game of war. 


\section{Confusion, Noise, Uproar and Terror in Battle; Their Effect Upon the Senses}

There are many unlooked for and unexpected phases of battle that always seem to have been overlooked or never considered in the cut and dried plans by officers in their zeal to fit men tactically for such an ordeal, and by the men themselves who have never been under fire. Among these phases are the confusion, noises, uproar and terror seen and heard for the first time, perhaps, all of which have, it will be found, a most important bearing upon their morale and stability. Until these factors are encountered they are but little understood in determining their own and the men's behavior when going into action. This is one of the most important things that should be called to the attention of the newly enlisted men, and it can only be done by careful personal instruction and practical talks and not by intensive drills, nor can it be fully taught by the noise and racket of sham battle. Too much emphasis cannot be laid on this. While he is diligently learning the salute, the manual of arms by the number, and "squads right" and "squads left," day after day in the training camp, attaining that perfection in the tactical drills which seem to be considered so absolutely essential by the average camp instructor in the real battlefield fighting for which the recruit or "rooky" is being prepared; the confusion, noises, din and terror which he will so suddenly and unexpectedly have to contend with when coming in contact with a real enemy-and of which he can know absolutely nothing-are, after all, among the most important factors to be considered. This should be frequently impressed upon him. It is seldom or never done.

To disabuse his mind in advance of all these disturbing noises and terrors that always attend, and which are necessarily a feature of every battle-but sometimes are used as a species of propaganda or camouflage of 
the real thing for the purpose of inspiring fear in the hearts of the uninitiated-it should become necessary and a part of the duty of camp instructors to eliminate as far as may be possible; in fact it is absolutely essential to a man's success as a fighter that the effect of noise upon the senses should be reduced to a minimum as a most powerful agent or contributing factor in impairing the morale of new men when the real shock of battle occurs.

Noise never won a battle; it never kills, but it is one of the hardest things for an inexperienced soldier just going into battle to disregard, to set it aside or get rid of the sudden and alarming effect of noise and uproar upon his senses. As a disturbing cause and moral depressent it will generally produce as much confusion and terror in his heart as stage fright upon a speaker when making his maiden speech or an actor when making his debut upon the stage. The impulse to stampede and to get away from this terrible noise, turmoil and deadly risk of battle is at first almost irresistible, and often uncontrollable. This utter demoralization on a battlefield by raw, inexperienced men was fully illustrated at the First Bull Run. The men were nearly all militia; they had had their surfeit of the manual of arms, and Scott's and Hardee's Tactics; plenty of barrack drill and maneuvers on a "Muster Field"_- "ad nauseam"but there was nobody to tell these overdrilled and tired men-except a very few Mexican war soldiers, of the noises and terror of a battle and, once thrown into a panic, they fled from the field like a herd of cattle. A little later these same men coming back in the threeyear regiments and under good, competent officers, and realizing after all what little damage was really being done, redeemed themselves; made light of the noises which had stampeded them before, and proved to be among the most efficient and bravest soldiers we had. Their officers had been green and nobody had taken any 
pains to explain or to instruct them as to what a real battle with its uproar and confusion meant. The whole mess was due to lack of practical instruction and not to lack of tactical drills.

The Chinese used this noise when beating their loud drums and gongs to confuse and terrorize their enemy. The savages used it when beating the tom-tom and uttering their high-keyed, shrill, ear-splitting yells, whoops and screeches. The Confederate used it during the Civil War when advancing their lines to the accompaniment of the "Rebel Yell," and for the same purpose, to strike terror in the hearts of the enemy. The Germans used all sorts of noises in the late World War. The incessant booming of guns and explosion of projectiles, with their deafening roar, resulted in producing a moral effect rather than in any damage or loss of life from their fire, since our casualties from artillery fire during the entire Civil War were less than one per cent. And yet, strange to note, all of the drum and tom-tom beating, this yelling, screeching, ear-splitting and noisy exhibition of courage by white and savage enemies alike, has a most terrifying, disheartening and demoralizing effect upon the new, raw, inexperienced soldier just entering upon his first battle-which the highly trained battle service line officer, with all of his morale and discipline intact, sometimes found it most difficult to repress, restrain or even to wholly control. The reason for all this is altogether hard to account for. Moral or physical cowardice -sometimes both-has been given as a cause. It may be entirely psychological. But, that it is a fact, and within the experience of many officers, cannot be disputed. Hence it becomes highly important; in fact it is absolutely necessary to eradicate or eliminate this human defect-for defect it is-from among any body of soldiers who are under training for battle, and at the start. Unless this is done one can never be wholly sure of even good men. The writer has seen on numer- 
ous occasions this effect of battle noise prove to be a veritable bête noir, and sometimes what might have proved to be a dangerous drawback to some men's morale and battle stability-not only the first time, but afterwards, or whenever they might advance in a battle line, unless meanwhile these same men may have become steady under fire. Sometimes, but not often, it proved permanent and incurable. It is the writer's belief that most men can be permanently cured by a sane talk before they are to be pushed into battle. "An ounce of prevention is worth a pound of cure." It seldom becomes a case of "cold feet" or cowardice-if taken in time. There is but little doubt, however, in the mind of the writer that many cases of so-called "shell shock" which occurred during the late World War, were nothing more nor less than "cold feet," inspired by the noise, confusion, uproar, and terror of suddenly being thrust into battle without having any previous intimation or knowledge of what its effect would be upon the senses-really the neglect of the drill instructor to instruct. Their morale was entirely destroyed. A little later, or in some subsequent battle, this same man could not be persuaded to quit the line. Once assured of the harmlessness of this kind of fighting, and this noise about him, he has become the reliable, trustworthy fighter which he might have been at first had there been an instructor competent to give him some reliable information on this point instead of so much tactical drill having been hammered into his brain which, later, he found he could not use. This sort of training is what the writer calls acquiring the battle sense or fighting balance, so necessary in teaching men who have the making of fine soldiers, the true "Art of Fighting." And it is a factor entirely apart from mere tactical drill or the "Art and Science of War." All of which leads to the conclusion that much time that is wasted in the non-essentials, and in tiring men by everlastingly pounding tactical drill into their heads day after 
day to make him a perfectly drilled man, could be better employed in practical talks that would fit the men for actual battle which really is not only the crucial test but the true object of military training.

The writer has been on a target range where skilled marksmen have been competing for high scores and the much coveted medals which are awarded for the same, and has been requested not to talk for fear of disturbing the contestants. In view of what these men would have to face in the way of noise in battle, to a battle-service soldier such a request brings a smile to the face.

It should be remembered that in actual battle the noise, din and uproar is so great that loud talking, or even the shouting of a command could not be heard even at a distance of a few feet. It is the writer's belief, therefore, that all sharpshooters, when battle efficiency is to be expected or attained, should be trained on the range under conditions approaching as closely as possible, or simulating those of real battle, with guns firing across the line, with projectiles exploding over the same, accompanied, if possible, by rifle and machine gun fire-with blank cartridges-this to steady the nerves, and as a real test of the ability to work under battle fire. This, it is believed, has seldom if ever been done. Not only that but they should be trained under all phases of weather, such as rain, hail, sleet and snow, for they are not going to lie under a shed and shielded from the sun in hot weather-as the writer saw at Camp Perry, Ohio, in 1913-nor by the side of a fire in cold weather. All this will not only test their mental and physical resources and powers of endurance, but their steadiness of nerves and ability to operate in the face of a real alert and skillful enemy under the conditions always to be found on a battleline front.

Too much stress has always been laid upon making scores for a record. If their nerves are not steady when people should happen to talk near the range, what in 
the name of common sense could they expect to do or what kind of a record could they expect to make when lying prone on the ground in a rain or snow storm under a heavy rifle and shrapnel fire from an active enemy, and from his concealed sharpshooters? They could not have hit a flock of flying barns. The writer saw both regiments of Berdan's Sharpshooters try to dislodge the Third Arkansas Confederate Infantry of the Texas Brigade, Hood's Division, Longstreet's Corps, from the "Devil's Den," all of July 3, 1863, at Gettysburg-both under perfect cover-without making the slightest impression on them, and yet every man in Berdan's command had been tried out on a target range before enlistment.

What is needed in our training camps is less of the drill sergeant in attempting to perfect men in mere tactical drill, (all that is necessary to put men into battle and take them out can be learned in a surprisingly short period) and more practical talks and practical instruction in the thousand and one things so necessary for a soldier to know on the march, in camp, on campaigns preceding battles-all by competent (and by competent is meant experienced) officers on practical battle problems and actual battle conditions on a battleline-so that they can be put into battle without their morale being shot to pieces before they actually begin to fight. Then we can be sure that we have got a real bunch of fighters, and not a nerveracked, demoralized, disorganized line of men who have got their minds so intently fixed on the noise and din that all of their training has gone for naught, and their fighting sense frozen out of them. Unless they have exceptionally good-fighting line officers and fine leadership, such men soon become as helpless as children-oftentimes seized with panic, and a stampeded herd of buffalo or cattle, or a caviard of horses is as nothing compared to a fear-crazed mob of men under 
fire. If this seems to be an overdrawn picture, the reader is referred to the stampede of the Eleventh Corps at the battle of Chancellorsville and Gettysburg, and the condition of Pickett's men at the "Bloody Angle" at Gettysburg after being shot up with rifle fire and canister on their front and a perfect blizzard on both flanks, all of which the writer saw. These men were, however, not even green men, but were experienced veterans of many battles. The illustration is offered to show how even trained men may be thrown into confusion and disorder by the noise, din and uproar of battle all about them, and the difficulty, almost impossibility, of maintaining tactical formations in the swirl and mix-up of a close contact and actual combat such as occurred on both of those battlefields and to an extent greater, perhaps, than on any other fields of the Civil War.

\section{Little Generalship Displayed}

There was little generalship on the fields of battle in which the writer was engaged. If Halleck, in his efforts to direct battles from Washington in the field by telegraph and long wirded, verbose and tardy orders, ever displayed any generalship nobody has ever discovered it in the long interval that has elapsed since the Civil War.

If McClellan, Burnside, or Hooker ever showed any, even if they were on the ground and were supposed to have a leadpipe cinch on the problems confronting them-the former even having had Lee's plan of operations at Antietam placed in his hands-nobody has ever found it out. There was little or no strategy, few, if any, tactical maneuvers, because, as has been shown, it was a physical impossibility to exercise any when the tactical or mathematical units had been either so destroyed or mixed up and disintegrated as to make it im- 
practicable in a wild-cat mêlée to reform commands. All this, as has already been cited, was most forcibly illustrated in the tangled thickets of the Wilderness, and in the woods about Spottsylvania $\mathrm{C}$. $\mathrm{H}$. where no tactical formations could be maintained for even five minutes at a time; but the lines held together and co-ordinated for fighting purposes through the almost superhuman efforts of the battle-trained line officers and the unimpaired morale and fighting spirit of the men-the same spirit which inspired Sergeants York and Woodfill in their magnificent achievements. The great battles were generally the men's battles; won by the deliberate, obstinate and desperate fighting qualities of the men in the ranks, provided their discipline and morale had not already been impaired or wholly destroyed through lack of generalship, or the weakness, indecision and rank cowardice of their immediate commanders-those officers who, in a crisis, should be their staunch and intrepid leaders. While declaring this, the writer does not wish it to be understood that there was no leadership. There was plenty, and of the right kind, and nearly all of the successes on either side can be attributed to these fine qualities among the magnificent field and line officers of brigades, regiments and companies-the men with fighting guts and the spirit of no defeat. There is as much difference between mediocre, book-worm, theoretical generalship and real leadership as there is between the "Art and Science of War" and the "Art of Fighting," or between a small windmill and a large dynamo which generates the electrical current with its wonderful power. Many a heroic act of some fighter along an extended line-as at Gettysburg-has gone down unrecorded except among the survivors of those bloody fields, which perhaps decided the contest at that particular point, if not, indeed, the battle itself. 
In the first place-and this is where the non-fighting or theoretical book soldier fails in his knowledge or even conceptions of battle conditions-in the uproar and confusion of a big fight no tactical commands could be heard, and if heard they were rarely understoodand if not understood and incapable of being executed for that and other reasons already given, of what use could they possibly be-and this is just where the leader and not the tactician came in, and is where his power was felt-that was just where common sense acts, not the tactical maneuvers, of Sergeants Alvin York and Woodfill became so effective after they were left to their own initiative, resources and skill as fighters. So far as the writer can learn, they had become separated entirely from their officers and were acting under the command or direction of nobody. A Hungarian officer applied the following remark of Napoleon at Lodi, "He knows nothing of the regular rules of war; he is sometimes in front, sometimes on our flank, sometimes in the rear. There is no supporting such gross violations of rules."

And so it might be said of any fighting soldier who knows the "Art of Fighting" and but little of the "Art and Science of War."

It then comes down to leadership pure and simple, and nothing more or less than that kind of leadership which we had in our boyhood days. That kind which never has been, and never will be taught from any books that ever were or will be written. It is possessed by few, especially by those who have stuck closely to the many textbooks written on the Art and Science of War and on carefully formulated plans of campaigns and battles. It can be cultivated, but it has got to be carefully studied as a trait or quality entirely apart from the whole subject of the theory and "art and science of uar," and entirely in connection with the "Art of Fighting." 


\section{Fighting Revolves About Leaders and "Scrappers"}

When all generalship seems to have failed on a field of battle and the fight has drifted away and is no longer under their-the corps, division and brigade commanders -eyes, then it is that the "Art of Fighting" steps in to take its place, and the real fighting sense of the men assumes its true value under the competent leadership of real fighting line officers. They are the real bullies, such as we saw in our desperate snow battles of seventy years ago in the old town by the sea on "Tar Bucket Night." The fighting always revolved or centered about them, and not around any regimental, brigade, division or corps commander after he had lost his tactical formations and directions-and the battle had assumed a more or less chaotic state, forcing him to rely in the end on the discipline, morale and leadership of his rank and file. These pages could be filled with examples. A concrete example of this was seen on the battlefield of Chickamauga when General Thomas rallied the fighting remnants of Rosecrans' army on Snodgrass Hill. It is related of the battle of Gettysburg that Lieutenant L. E. Bicknell of the First Company of Andrews Massachusetts sharpshooters, who had but twenty of his men with him-by direction of General Hayes, commanding the Third Division, Second Corps-gathered parts of several regiments which had become partially disorganized by the Confederate cannonade that had been concentrated upon Ziegler's Grove; he formed them in line. They were drilled a few minutes in oblique firing; he advanced from the grove, wheeled them to the left up to the fence on the north side of Bryan's Lane, which ran west to the Emmettsburg Road, and when Pettigrew's columns supporting Pickett's charge were passing along the south side of the lane and crowding through it, he, with the cooperation of the Eighth Ohio Infantry, which had wheeled in to his right across the Emmittsburg Road, 
opened a deadly fire upon their left flank which made them sag off to their right against Hayes' Division (Third) of the Second Corps. Then, drawing back his line, thus uncovering the section of a battery at Bryan's house, he allowed these guns to sweep the lane and Pettigrew's flanks, which practically drove him (the latter) from the field and won the battle at that end of the line. That was the fighting spirit of a young volunteer lieutenant. General Longstreet wrote him a letter in 1884 which corroborates Bicknell's own statement, in which he credits Bicknell with performing an act at a critical moment which contributed largely to the defeat of Pickett's supports on that flank, and he adds: "The breaking up of the supporting force broke up the attack or hope of success from it. We could not look for anything from Pickett except to break your line. The supports (Pettigrew, Trimble, Wilcox and Perry) were to secure the fruits of that break."

\section{Two Peerless Fighters at Fredericksburg and Gettysburg}

The writer's captain, during the Civil War in the Twenty-Second Mass. Vol. Inf., was Joseph H. Baxter, a cigar maker, of Cambridge, Mass., and the first lieutenant was Charles D. Knowles of Haverhill, Mass., a shoe cutter, but a man of considerable education. We spoke of them, but not to them, as "Joe" and "Charlie." Both were mortally wounded and died of their wounds in a few hours-one at Cold Harbor (Bethesda Church), the other at "The Loop"-dying in Henry Spangler's barnyard on the Baltimore Pike at Gettysburg. Both knew the "Art of Fighting," and while neither objected to being called by their Christian names, nor to bivouacking and messing from our haversacks or drinking from our canteens on the march, in event that their blankets and rations did not come up by dark on the pack mules 
or in the wagons-no familiarity was permitted, and proper discipline and the fighting morale was always maintained. We were sometimes addressed as "Bob," "John," "Bill," etc., and frequently on a battle line and under a heavy fire they would from the rear (line of file closers) shout: "Stick to 'em, Johnny!" "Give 'em h-l, Bob!" etc. No one could slap them on the back or perpetrate any jokes at their expense. Both were short and stocky-one (Knowles) with sandy hair and moustache, with steel blue eyes and bulldog chin, the other (Baxter) with curly chestnut hair, moustache and goatee, and deep-set blue eyes and heavy, square, fighting jaw.

At Fredericksburg, two hundred yards from the "Sunken Road" at the foot of Marye's Heights, the writer's rifle, after about 60 rounds, became so hot and foul that the rammer jammed. A sudden impulse seized him, and he fired rammer and all into a mass of forms showing through the battle smoke, and then looked backward with a mute appeal for help. Baxter shouted above the din, "What is the matter, Bob?" The useless rifle was raised. Quick as lightning came the command to the first sergeant, "Quick, Charlie, pass Bob another rifle!" A new Springfield, picked up from among the dead of the 12th R. I., Ferrero's Brigade, Sturgis' Division, Ninth Corps, among whose dead and dying we were then fighting, was rapidly passed over the heads into the front rank, and the firing was instantly resumed with no other comments. But the bellowing notes of Baxter, our fighting captain, could be heard above the uproar. "Give it to 'em!" "Fire slow and low!" That's the time you got 'em!" "Shoot the h-l out of 'em!" etc. All of that bitter cold night we lay among the stark dead and the moaning, shrieking, imploring wounded with no first aid packets or stations; no emergency, evacuation or base hospitals, and not an ambulance or stretcher bearer could approach the battle-line from the direction of the town, every inch of ground being "cov- 
ered as with a fine tooth comb" as thus described by Gen. D. H. Hill when requested by General Lee to report the condition of the defences on his front.

There could be no advance or retreat from this position, and there was no head cover or breastworks except the stiff, half-frozen corpses all about us, which we soon utilized as there were no intrenching tools available. We had no food except a little cracker dust in the bottom of our haversacks, and there were no "rolling kitchens."

From dawn until night closed in again the next day, or, for sixteen long, weary hours we lay under a constant withering rifle and plunging shrapnel and canister fire from the heights, being able to move only from one side to the other or on our backs to avoid exposing our heads, the bodies of both the dead in front of and the wounded around us being struck again and again, until they had lost all semblance to the human form.

When finally relieved at 8 o'clock there was no "rest area," merely a cold, cheerless bivouac on the frozen ground, and without camp fires, on the banks of the dark river full of floating ice.

Throughout this almost appalling situation these peerless fighting volunteer leaders, these matchless fighters, never gave signs of weakening. Knowles roused the living survivors from the blanketed dead, issued cartridges to renew the contest, and Baxter, in the quickening gray of that terrible morning, moved the company through the cold mist and battle smoke a few yards forward on the line, and the noise, uproar and din began again, never to cease until another night with its chilling darkness and gloom shut down. Their voices were strong, firm, cheerful and always inspiring. Never for a moment did they show the young boys under their command that their courage was waning or flagging; that their spirits were wavering or drooping, or their morale was other than that of the perfect battle-trained and disciplined soldiers that they were then and were ever after-on the march, in bivouac and in battle up 
to the moment when their souls went on to meet their Maker on the fields of Gettysburg and Cold Harbor.

What was Burnside doing during these hours of uncertainty, of doubt, gloom and unnecessary slaughter of our brave fighters? He was milling around with no well-defined plan for extricating himself from his perilous dilemma, but engaged in formulating a vague, fool scheme for another desperate assault upon the "Stone Wall" and "Marye's Heights," and menaced by Lee, who might have opened fire upon our closely huddled up masses, only being deterred from doing so out of consideration for the inhabitants of the town who were to come back and occupy its shell-torn houses, and firm in the belief that the enemy would sooner or later be compelled to evacuate. Burnside was only dissuaded from his rash project through the plea of one of his old Zouave colonels (Colonel Rush Hawkins) after we had been ordered into another all-night battle-line in the main street with the assault to take place at daybreak.

Burnside lacked the even balance and good judgment of a wise, sane and safe fighter.

Knowles was hit directly behind the boulder in the "Loop" at Gettysburg, on which was placed many years ago the handsome monument of the "Henry Wilson Regiment" (Twenty-Second Massachusetts Volunteer Infantry), falling behind the writer just as he was shouting his last words of encouragement to the men in that death-strewn spot. He died as he had lived-the brave, uncomplaining, clear-eyed, clean-minded type of men who, while they studied grand strategy and tactics but little if at all, were the true exponents of those officers who won the battles of that war, bcause they fully understood the real "Art of Fighting," and had the ability to impart-not tactically but morally - that fighting spirit to the men under them and to hold them to their work in a crisis when under fire. 
While they were not book-fed or theoretical soldiers they could get the best of results from, and the loyal cooperation of, their men, who were attached to them because they had real faith in them. No braver men, who knew and placed at its true value the real art of fighting, ever went into battle than "Joe" Baxter and "Charlie" Knowles, our peerless volunteer leaders of the Civil War. They had the genuine fighting guts and spirit, and were in every respect typical fighters of the old Army of the Potomac. All honor to their dauntless souls. Peace to their ashes! And there were thousands more like them and many other grim fighters and gallant spirits who knew the true "Art of Fighting" in that veteran volunteer regiment; among them Captain "Ben" Davis and Sergeant "Andy" Wilson, who captured the battle-flag of the Sixth Alabama Infantry, Battle's Brigade, Rode's Division, Early's Corps, in a midnight, hand-to-hand combat in the woods at Spottsylvania Court House ("Laurel Hill") May 8, 1864. They were a mile or more away from the main command and the eyes of their field officers, and upon emerging from the forest at daybreak, on the 9th and gaining the Brock Road near where Gen. Sedgwick fell, both were killed, one within a few hours that same day; the other on the 10th near Alsop's Farm. The splendid initiative and morale of such magnificent fighters can never fade from history's pages.

No monumental inscription or vaunting epitaph could add to the glory of such gallant fighting spirits so long ago hushed in death on those historic battlefields.

\section{Lee's Failure and Jackson's Stupendous Success Due to Battle Psychology, and Not to Any Art and Science of War}

In no battle of the Civil War did Robert E. Lee commit such a fatal blunder-the most charitable construction that one can place upon such an act-as when he, 
trying to adhere closely to the Art and Science of War, issued the order for Pickett to attack, with supporting units, the Union center at Gettysburg, instead of taking General Longstreet's advice to try and turn the Union left flank, interpose between Meade and both Washington and Baltimore, in an effort to compel Meade to make an offensive attack on him instead of remaining in a defensive position, which he (Meade) had selected. Longstreet knew the Art of Fighting and his keen battle sense saw at once the futility of such an assault, after the Union right and left had been firmly secured, and there remained open to Lee what he believed was his only alternative-an attack upon a strongly held center. $\mathrm{He}$ had no more chance for success than did Burnside when he made his fatal attack at Fredericksburg in an effort to carry Marye's Heights in rear of that city in the face of such insurmountable obstacles and a perfectly devised plan of defense.

In no battle of the Civil War did Jackson so grossly violate every principle taught in the Art and Science of War as at Chancellorsville when, after a long, grueling march, by which he separated himself from Lee by at least twelve miles, he made his famous attack upon the right flank of the Union Army near "Wilderness Tavern." But Jackson did not drink whisky; was a sober man, and withal he was a fighter and knew the "Art of Fighting." It was the craziest move ever undertaken in the face of a powerful army and after the battle was on. Such a move never had the remotest chance of success except in the event of his opponent being paralyzed, or inert and helpless from causes not then known but which have become well known since. It is most amazing that a general like Lee, with a cool, calculating judgment, perfect poise, and correct balance in battle should have ever permitted such a foolhardy maneuver to be set on foot by one of his corps commanders. 
It is possible, however, that both Lee and Jackson may have known that Hooker had been drinking hard all that winter and was unfit to command so large an army in the field. At least they must have judged, and judged rightly, that something was the matter with him (Hooker) when, having initiated his move against Jackson's Corps on the Fredericksburg Turnpike on Friday, May 1, to get into open country for an offensive battle, and had successfully pushed him back, he suddenly issued an order to regain his original lines, and not only lost the fruits of such an advance but his initiative and all hope of again recovering the ground thus so mysteriously abandoned. Jackson's Corps became, however, a tactical wreck in the woods after driving back the 11th Corps and was so mixed up and disorganized the next morning that "Jeb" Stuart, who was designated by Lee-A. P. Hill being wounded-to temporarily succeed Jackson, after the latter was mortally wounded, took several hours to reorganize it on Sunday morning, May 3, and put in a condition so that it could advance upon the Union lines at "Fairview" near the Chancellor House, with any hope of success. Jackson never could or should have succeeded in such a crazy move had "Fighting Joe" Hooker not been filled up with "booze" or in a condition which was the effect of "boozing," and any statement that he (Jackson) could have passed his inextricably mixed up and disorganized corps that night along the narrow wood road leading from the Orange Plank Road to the rear of the Union position near Mineral Springs-as believed by some military authors -is not only mere conjecture but all moonshine based upon what Jackson wanted to do. There were 30,000 men of the First and Fifth Corps across that road almost all of that night, looking for Jackson to deploy his corps in such a narrow space, and before he could possibly have had time to disentangle it and march it to that point. It was out of the fight for at least that night. The military student has only to go 
to that point and see for himself and go afoot and not in an automobile-and with somebody who knows the battlefield-and not with one of these windy battlefield guides and lecturers who has memorized a lot of bunk from books written by persons who were never in that or any other battle, and who is not familiar with the terrain.

It seems then that this matter comes down to the "Art of Fighting" rather than to the "Art and Science of War;" less theory and more practice as well as power of action.

Then let all of our future instruction be devoted to teaching our young officers the "Art and Science of Fighting" instead of so much theoretical book bunk that does not nor ever will fit into the conditions of a real battle when people are getting killed and wounded every minute, and battle conditions sometimes approach an almost chaotic state.

What we need today and will need in our army at all times in the future, is leadership, and then more leadership_or fighting leaders-and fewer bookworm, theoretical soldiers and service school students. The latter are almost always the first to fall down in a real battlemixup and take rank, not as battle soldiers, but as battle fakirs.

\section{The Marines at Gettysburg}

The nearest approach in time of peace, to anything like a genuine test out of campaign and battle conditions which the writer has ever seen since the Civil War, and that seemed to have any true value in fitting men for fighters in the game of war, was the practice march of the Expeditionary Force of marines under command of Brig.-General Smedley D. Butler, U. S. M. C., from their camp at Quantico, Va., to Gettysburg, $\mathrm{Pa}$. , and return, 
June-July, 1922, and the enactment of the historical pageant of "Pickett's Charge" at Gettysburg, July 3, and the more modern methods of battle, July 4, 1922, at which the writer was present as an observer, through the courtesy of General Butler-also of Gen. Geo. Richards, P. M. General, U. S. M. C. While the camp at Gettysburg, with its electric lights, bath tubs, beds, rugs, running water, etc., was luxurious in the extreme, almost marvellousespecially the "White House" erected for the Presidentfrom the standpoint of a Civil War veteran of 60 years ago who was in that battle but who had no tent and little to eat, but who saw that charge from start to finish from the high slopes of Little Round Top, and the simulated battle was more or less spectacular-more like a moving picture-as it had to be unless real fighting was taking place, and while the tactical formations also remained unbroken in the advance of the battle line across the field from Seminary Ridge to the "Angle," while nobody was being killed or wounded, yet it was, nevertheless, well staged, and realistic to a point where it only needed a few accessories such as live shot, shell, canister, and bullets ploughing into masses of men, and the inextricable confusion and mixup always produced thereby, to make it an approximately true picture of the real clash of battle at that point only lacking those wild and horrifying features of such a contact that no writer can describe, no artist portray and no peace maneuver can accurately stage. They were a fine body of men and went at their work in the rain, drizzle and mud with the zeal, energy and enthusiasm of men who had been well trained-but not too finely trained-by battle-taught instructors, who knew how to impart their knowledge and apply it in such practical and valuable battle maneuvers as these, in every sense of the word, proved to be. The writer saw these so-called "Devil-dogs" before, during and after this mimic battle-when they had got the dust of the road and the mud of the fields cleaned off-and they 
surely came fully up to his idea of as fine a bunch of husky "Leathernecks" with no paper collars or varnish on them as he had seen in many a day. There was no umpiring, no far-fetched decisions based on theoretical bunk or casualty tables; simply a first class and most realistic battle maneuver "pulled off" in a most practical fashion-and Gettysburg proved to be an inspiration.

\author{
"Bushido" \\ The Spirit of the Men of Arms \\ (Paraphrased from the Japanese)
}

I.

The supreme duty of the soldier is loyalty to country. Most of those born in this country are not wanting in a sort of patriotism, but for the soldier, patriotism of the highest quality is so essential that without it he is of little worth. Many men are stirred to temporary emotion at the sight of the Flag or at the sound of martial music, and then as quickly forget; but with the soldier love for his country and devotion to his flag must be ever present and rooted in his inmost being, nerving him and sustaining him, not only in the dangers and hardships of war, but in the discipline and training of peace. He should not, therefore intangle himself overmuch in matters political and social, remembering that he belongs not to a party or class, but to his country as a whole regarding his supreme duty of loyalty. This duty should have for him the weight of a mountain, while death itself should be lightly considered in comparison.

II.

The soldier must have due regard for the rights of his superiors and subordinates, and his duties toward them. In an army there are various grades of rank, all of which are necessary for efficient and harmonious action. The junior must obey and respect the senior and the subordinate his superior, with ready willingness. Superiors must never be haughty or capricious toward those lower in rank; and severity must be reserved for wilful disobedience or carelessness. Dignity is best sustained by simplicity and kindness without undue familiarity. If juniors treat their seniors with dis- 
respect, or seniors treat their subordinates with harshness and injustice, it is impossible for the army to unite harmoniously as one man in the service of the country. All soldiers of whatever degree must remember that they are associated in a great and honorable service and that they serve worthily in the station in which each is placed is an honor in which the private participates as fully as his general.

\section{III.}

It is necessary that the soldier have both courage and fidelity. Although it is natural for men to shrink from toil and hardship; to fear wounds and death, the soldier must have courage and endurance, and that far more than other men. He must, therefore, cultivate these qualifications, making every effort to render his body hardy and vigorous, and preparing his mind in advance for any demand or sacrifice his country may require of him. He should study and emulate the valor of the men who in time past have fought under his flag, and be ever mindful of his supreme duty to his country, in comparison to which the death of one man, or even many men, is a very little thing. The soldier's courage should be exercised with judgment and reason. He must never despise his enemy although they be but few in number; nor to fear even a large number, knowing that strong-hearted determination is always superior to mere numbers. He must not expect to obtain honor in ease and safety. His calling is honorable because it is hard and dangerous and calls for stronger bodies and minds than are commonly found among men.

\section{IV.}

The soldier should observe the highest degree of truth and uprightness as well as strict fidelity to all his engagements. His word must be truth and his promise sacred. This must be so not only because of consideration of honor, but because the sure and successful conduct of military operations depends upon the mutual confidence that otherwise cannot prevail. To tell exact truth is not always easy even with good intentions. The soldier, therefore, upon whose word or report much often depends, must use great care to state no more and no less than the entire truth. Before making an important promise or engagement he should consider with care whether the thing can be done or whether it ought to be done. But when he has once passed his word, whether with friend or enemy, he should be faithful to it if by any means within his power. By such conduct he will inspire the confidence of his superiors, the respect of his subordinates and the fear of his enemies. 
V.

It is the duty of the good soldier to be simple and temperate in his life and habits. This is the only way by which he can maintain strength of body and vigor of mind. Soldiers who allow themselves to become accustomed to luxury are led to extravagance and to too great a desire for wealth. They thus become weak, false-hearted and ignoble, and forget and abaridon the virtues of loyalty, fidelity and courage and become unfit for their calling.

These five articles are the spirit of the Men of Arms; and the true heart is the spirit of the five articles.

If the heart is not true, good words and good talk are but useless ornaments.

If the heart be true you may accomplish anything.

If you serve your country in accordance with this advice, you will profit it much and earn honor and respect to yourself.

\section{Conclusion}

Many of these camp trainers were young graduates of West Point and officers of the National Guard, perhaps later some officers from the Plattsburg Camp; many were without practical experience except in drill and maneuver camps. They were of the right stuff, fine drill masters and good disciplinarians and did fine work, but a great many were poor instructors because they begun their teaching at the wrong end, and because they were entirely lacking in any practical knowledge of war which could be imparted to men who were supposed to be preparing -and with no time to lose-for immediate and effective battle service, with a war already in progress and a hurry call, which seemed imperative, for American troops which, upon landing in France, were to go at once upon the battle line and become scrappers and fighters alongside the Allies in a desperate struggle, not only to save the civilization of the world, but to protect and make secure our own institutions. The writer has referred to the manner of training; that it should be by competentand by competent is meant experienced-officers. He 
further means battle-taught instructors, or as nearly approaching thereto as possible, of whom we unfortunately had too few in our training camps. The Civil Wartrained fighters were not utilized on account of their age-and because, perhaps, they did not fit into the German method of fighting from furnished underground apartments and dugouts, although their suggestions and advice might well have been accepted and proved of some practical value.

The camp trainers could not readily get away from the setting-up-plebe-squad drill and militia barrack bunk, and all of the absolute and soldierly perfection in tactical drill which every one in our army knows has been, is, and always will be the pride of every graduate of the Military Academy, but which should have been, and at the start, subordinated to training more essential when facing up to a grave war crisis, and better suited to its needs. It was not quick preparation for war so long as preparedness with us had been such a long and sadly neglected duty. Neither was all of such training really adapted to battle conditions - as was found after most of our troops reached France. Most of the British officers who visited those camps referred to it, in their impatience, as "just 'slogging' along."

After all of these criticisms, which many will declare are not constructive but merely broad statements, "knocks," "kicks," complaints and hints, without suggesting any remedy; and coming as they do from a Civil War graduate of the Military Academy (there are but few of us left), one might ask for some explanation; perhaps some concrete example as to how, under the circumstances, these conditions could have been remedied, or what other methods or changes in the system-as designated by the General Staff-could be made in event of any future rapid training of men for immediate war, and when the time might be limited to a few weeks or months. 
In reply to such a request the writer would freely state but in very general terms (for there are too many problems involved and these pages would hardly contain them all) that he would begin this training just where these zealous and most efficient drill masters or instructors left off. A man's weapons are the first consideration in battle, and when properly backed up by sand (courage), morale and discipline and directed by intelligence, then you have the soldier. Beginning with their weapons, which, it is repeated, are of the first importance, much more so than salutes, manual of arms and unimportant tactical drills; after giving these green, inexperienced men just enough "School of the soldier," and "School of the Company" so that they could march to and from their formations - company, squad, etc., and to the target range-and just enough of the manual of arms so that they could hold their pieces properly at an order, carry -right and left shoulder and present-all this for preliminary discipline and to perform the necessary camp guard duty, etc., but without wasting any time on the niceties or attempting anything like West Point perfection, then the writer would march them daily to and from the target range (giving them the necessary talks and lectures on guard and picket duty, the regulations, articles of war, etc., ad interims-during evenings, if pressed for time, or on stormy days when they could not go on the range), and carefully teach the perfect use of their weapons-giving them the very best instruction under the most skillful experts, putting in all of the training, drilling, discipline and perfection right at this end of the period, and to the maximum limit, so that their knowledge would fit them as rapidly as possible for marksmen, sharpshooters, snipers and all-around, selfreliant skirmishers or raiders. All this would inspire them with a confidence that could be acquired in no other way-certainly not by incessant tactical drill. It would be of the greatest value to them-even should they receive 
no other training-should occasion arise-as it might and almost always does-after the formations should be broken up, and when they might be separated from their company and squad leaders. This would be the time when such training counts and tactical drill does not, and when their initiative, born of full confidence in themselves, would be given full play.

Their marches to and from the range would harden their muscles and keep them in fit condition, but if the distance was not far enough that could be increased by a detour daily, but gradually, so as not to weary them. During these daily marches they could be exercised in the deployments forward, to the right, left and centerall of which could be taught in a few lessons without any waste of time and be a part of the program for general instruction, co-ordinated with the range training, without making it special, tedious or tiresome. A few minutes' exercise in "setting up" before going to the range-en masse, a la Koehler-instruction in pitching dog (or "pup") tents, packing, adjusting and carrying their packs (which should be light-below the theoretical load-unless it is to go on motor trucks, for men cannot expect in war the comforts of a home), telling them just what to take, what to leave behind, or what to dump should some unforeseen emergency compel them to make several forced marches, and to go into battle to save the day; how to take care of their feet; cleanliness, etc.this in the form of individual instruction by the best noncommissioned officers under the closest supervision of competent company officers-making the inspections very frequent and most rigid, even up to the time of going into action, to see that the arms, ammunition and every part of the equipment is fit for instant battle. In other words, instruction to take the place of tactical drills. All this has already been outlined in this paper. There could be many more details suggested that are not, and could not, be mentioned here, or, except by a carefully arranged 
plan or schedule worked out by the General Staff along this general scheme; most of these, however, would suggest themselves to any zealous officer competent to look after his men and to their perfect battle condition and fighting efficiency. All this should be done by frequent talks, lectures and individual instruction, these taking the place of, or cutting out, so much incessant drill in the attempt to make a tactical machine out of them. It would be practically impossible to give any cut and dried formulas or daily schedules for working out such a system of instruction.

Such a scheme could only be given in general terms and then gradually developed according to the time to be given, which, of course, would be more or less, if not absolutely, governed by the particular crisis demanding such a quick emergency training.

The entire matter, it should be noted, is a practical suggestion and its application to a shorter method for fitting men in the "Art of Fighting" after war has already been declared; little or no preparedness in sight, and when time is so short that any other training is a mere waste of time and energy in an attempt to perfect men in things that will generally prove to be non-essential in real battle service.

How long would this take, it might be asked, to fit men in a training camp to become good fighters? Provided there were not too many camp non-essentials; too many ceremonies-such as reviews, parades or receptions for the President, Members of Congress, the Secretary of War and other high officials, etc.-or "you tickle me and I'll tickle you" stuff, so that a lot of tactical drill might then become necessary to hammer into the men to fit them or make them "smart" for this absolute waste of time during a critical war period-and dependent somewhat upon the season and condition of the weather-the writer would say from two to three months, i. e., provided they had battle-trained instructors during the entire period 
who would work hard. If a sudden emergency call should come it could be cut down to a very much shorter period.

The writer, who had never been in ranks or handled a rifle before August 5, 1862, was trained in an old veteran regiment on the march from Bull Run to Antietam - strictly from September 3 (time of joining the regiment on the march) to September 16-and later, at infrequent intervals in camp near Sharpsburg, Md., up to October 31-between two men who had been in the "Seven Days' Battles" on the peninsula from Hanover Court House and Gaines Mills to Malvern Hill. He went loaded very light by advice of his new comrades, to avoid exhaustion on a forced march in hot weather $\left(98^{\circ}\right.$ on September 12), thereby enduring many unlooked for hardships. He was handled or trained by Sergeant William ("Billy") Salter, a fine drill sergeant, who had also been in the National Guard and "Three Months' Service." No time was wasted in "frills," "lugs," "shams" or "furbelows." We were expected to meet the enemy almost any hour. He was carefully taught the use of his rifle first, after being shown how to "fall in;" the facings; then guard and picket duty, methods of challenging, etc. There was no time spent in right and left hand salute, manual of arms or useless tactical drills. He got that, and in the simplest manner possible, on the march. The writer, upon going into battle, soon found that the peninsula veterans had "nothing on him," and the word "drill" was never again mentioned to him from that time until his discharge in October, 1864. We were none of us sharpshooters. We didn't have to be as the enemy was generally near enough for point blank firing, and we had a company of sharpshooters attached to the regiment. There were very few drills ever had in the regiment after its first period of training, as it had been commanded by a regular officer, Captain Jesse A. Gove, Tenth U. S. Infantry (later colonel, 22nd Massachusetts Volunteer Infantry), from October, 1861, to June 27, 1862, when 
he was killed; and it was a finely drilled and disciplined body of men. The writer soon picked up all of the tactics that were necessary for him to get into battle, or to get out, and had accumulated all the confidence that any youngster is bound to possess who has been properly trained by competent battle-taught officers-and mingling closely with men who had been on numerous campaigns and seven battles where the enemy could be seen close up -and not concealed by dug-outs and gopher holes or subterranean shelters-no matter if the time had been so very short.

Of course he didn't make such a very noticeable splurge in the manual of arms or in tactical drill when he entered West Point in 1865, but in a few weeks and under a very smart but most disgusting yearling corporal, he managed to get most of the old Army of the Potomac mud and rust off of him; accumulate quite a little "pep" and "punch;" attend all of the drills and parades, perform camp guard duty, etc., without many blunders or stepping on anybody's heels in ranks, and the following year was himself a proud cadet corporal and a cadet officer the years following-all of which did him no harm after he joined the Fourth Cavalry and hunted the wily Comanches, Kiowas and Cheyennes on the plains of Texas.

It had made him a little straighter, a little smarter in appearance and had given him a little more knowledge of mere perfection in tactical drill. It afforded him a very valuable education and opened up the possibilities of an honorable and much-desired career. (Unfortunately cut short by a terrible injury received in action with Indians). It added nothing, however, to his knowledge of the "Art of Fighting" which he had gained years before on the bloody battlefields of the Army of the Potomac, or made of him a better soldier. Nor had it aided him in any way in securing the Congressional Medal of Honor-two brevets-one for "Specially Gallant Conduct," and a letter of congratulation and special commen- 
dation for "Zeal, Energy and Ability" displayed in the capture of ten (10) deserters under circumstances of exceptional hardship and peril-the record capture in the Military Department of Texas-and the "Grateful Thanks" of the State of Texas for "prompt action" and "gallant conduct" in "ridding our border of those scourges" (the Indians), in addition to a letter, upon leaving the Fourth Cavalry from General Ranald S. Mackenzie, then its colonel, with the following brief tribute: "You do not know, my dear C-, how sorry I am to lose you from my regiment. Sincerely, your friend." 












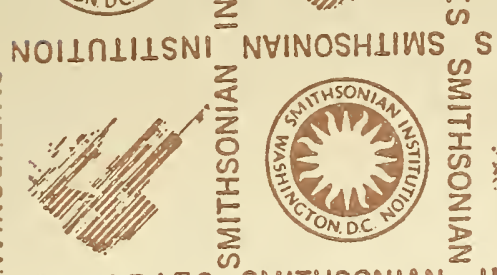

es

SMITHSONIAN $=$ INSTI

LIBRARIES SMITHSONIAN
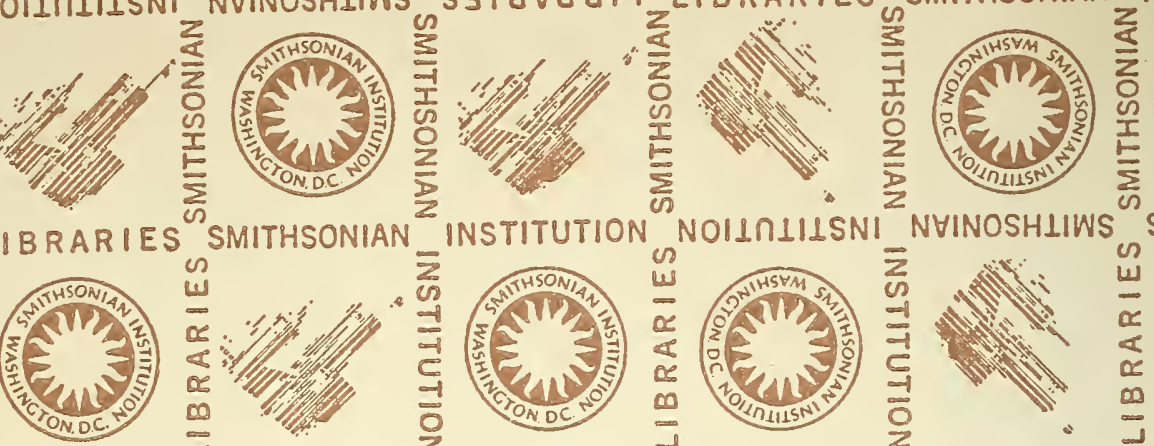

NOHIIIISNI ${ }^{d}$ NHINOSH1IHS
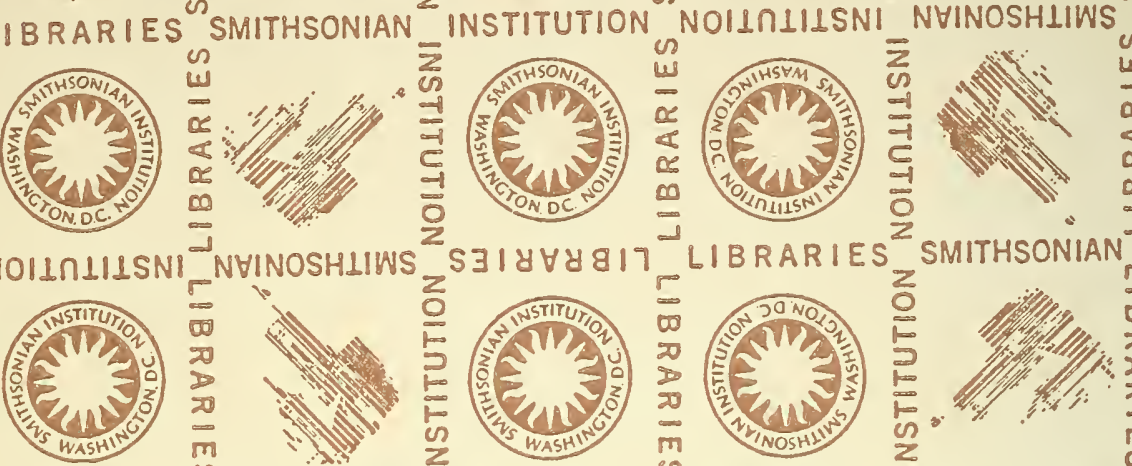

S $\exists I d$

LIBRARIES
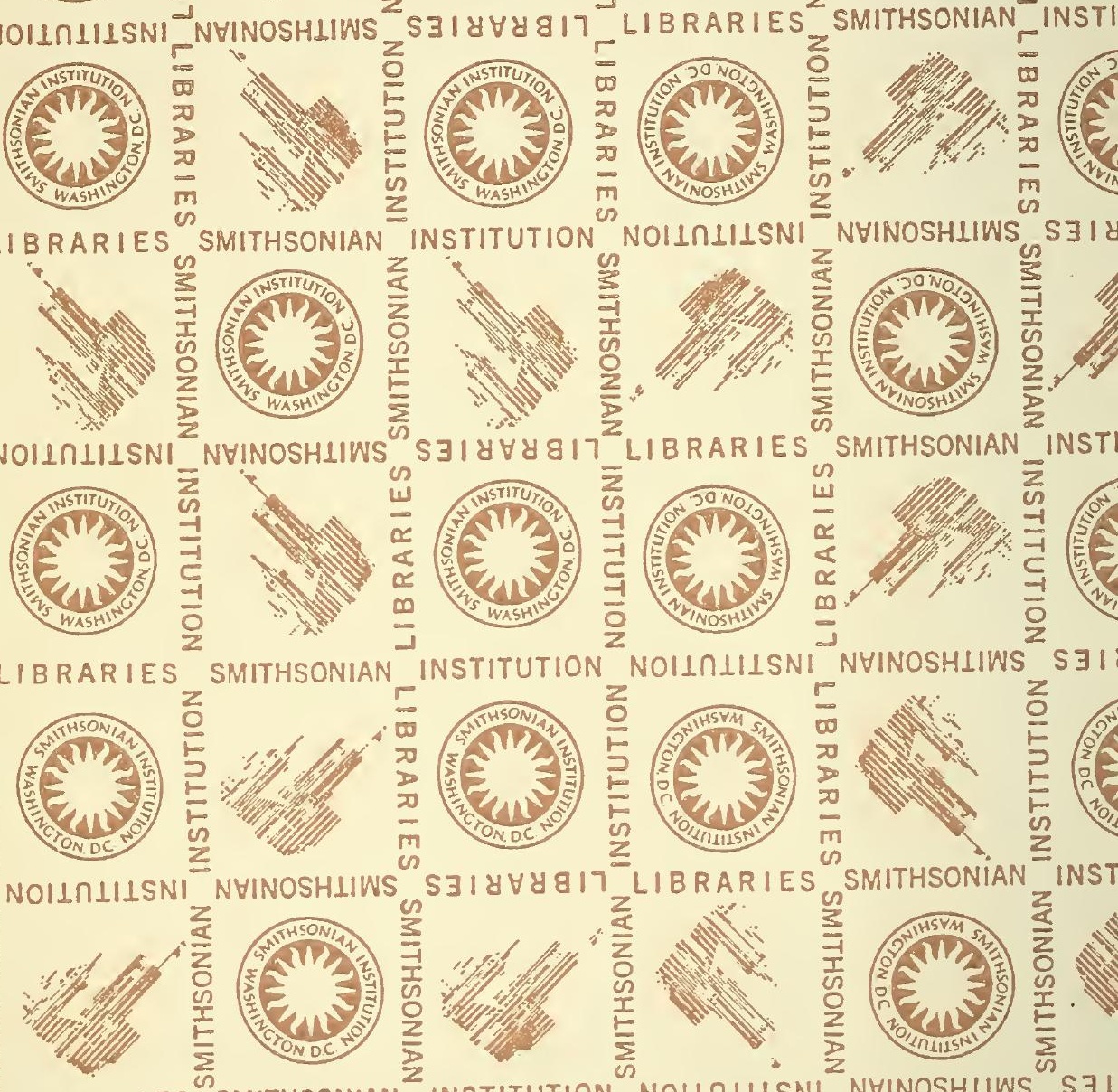

SMITHSONIAN
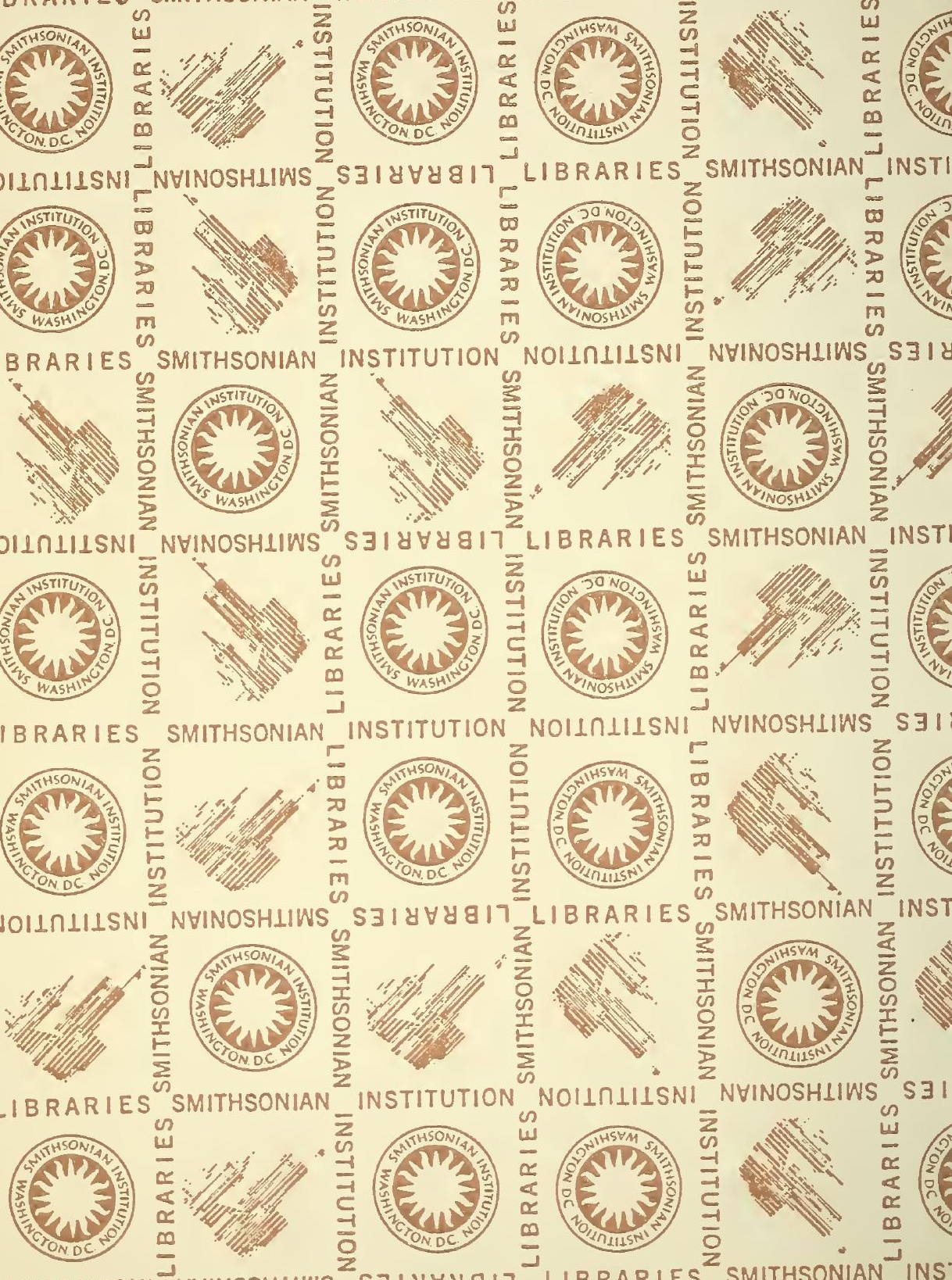

S $\exists I$
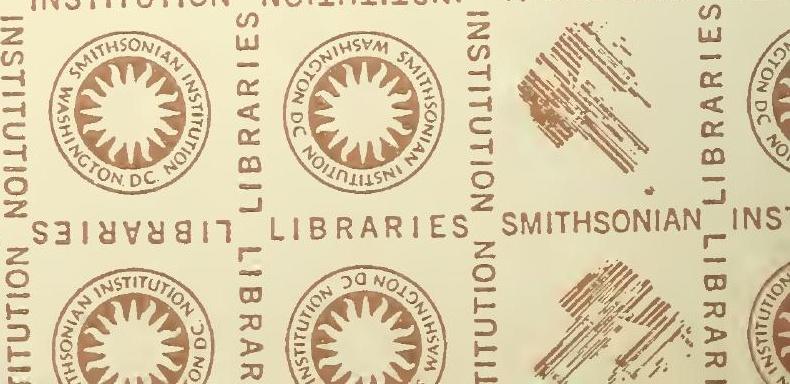
